\begin{abstract}
Universidade de São Paulo
Faculdade de Odontologia de Ribeirão Preto

Departamento de Cirurgia e Traumatologia Buco-Maxilo-Facial e Periodontia
\end{abstract}

GUSTAVO AUGUSTO GROSSI DE OLIVEIRA

EFEITO DA SUPERFÍCIE HIDROFÍLICA NA OSSEOINTEGRAÇÃO DE IMPLANTES EM SÍTIOS COM DEFEITOS ÓSSEOS CIRCUNFERENCIAIS:

ESTUDO EXPERIMENTAL EM CÃES

Ribeirão Preto

2012 
Universidade de São Paulo

Faculdade de Odontologia de Ribeirão Preto

Departamento de Cirurgia e Traumatologia Buco-Maxilo-Facial e Periodontia

GUSTAVO AUGUSTO GROSSI DE OLIVEIRA

\section{EFEITO DA SUPERFÍCIE HIDROFÍLICA NA OSSEOINTEGRAÇÃO DE IMPLANTES EM SÍTIOS COM DEFEITOS ÓSSEOS CIRCUNFERENCIAIS: ESTUDO EXPERIMENTAL EM CÃES}

Dissertação apresentada à Faculdade de Odontologia de Ribeirão Preto - USP, como parte dos requisitos para obtenção do título de Mestre em Cirurgia Buco-maxilo-facial.

Orientador: Prof. Dr. Luiz Antonio Salata

Ribeirão Preto 
Autorizo a reprodução e divulgação total ou parcial deste trabalho, por qualquer meio convencional ou eletrônico, para fins de estudo e pesquisa, desde que citada esta fonte.

\section{Grossi-Oliveira, Gustavo Augusto}

Efeito da superfície hidrofílica na osseointegração de implantes em sítios com defeitos ósseos circunferenciais: estudo experimental em cães. Dissertação de Mestrado apresentada à faculdade de Odontologia de Ribeirão Preto/USP. Área de concentração: Cirurgia Buco-maxilo-facial Orientador: Salata, Luis Antonio

p.: 74, il; $30 \mathrm{~cm}$ implantes dentários; superfícies de implantes; hidrofobilidade. 
Folha de Aprovação

Gustavo Augusto Grossi de Oliveira

Efeito da superfície hidrofílica na osseointegração de implantes em sítios com defeitos ósseos circunferenciais: estudo experimental em cães

Dissertação apresentada à Faculdade de Odontologia de Ribeirão Preto - USP, como parte dos requisitos para obtenção do título de Meste em Cirurgia Bucomaxilo-facial.

Orientador: Prof. Dr. Luiz Antonio Salata

Aprovado em: $/ 2012$

Banca Examinadora

Prof. Dr.:

Instituição: Assinatura:

Prof. Dr.:

Instituição: Assinatura:

Prof. Dr.:

Instituição: Assinatura: 
O sucesso nasce do querer, da determinação e persistência em se chegar a um objetivo. Mesmo não atingindo o alvo, quem busca e vence obstáculos, no mínimo fará coisas admiráveis." (José de Alencar) 


\section{DEDICATÓRIA}

À minha esposa, Vanessa Silva Grossi, por sempre ter estimulado meu crescimento profissional e entendido minha ausência em momentos difíceis. Todas as minhas lutas, acredite, são por você. Te amo.

À minha filha, Manuela Silva Grossi, apesar da pouca idade já desperta um amor em mim que até então não conhecia. Observar você crescer a olhos vistos, transformando sua marcha curta e frágil em corridas seguras é uma experiência mágica. Obrigado por ter me dado o "título" de pai e a oportunidade de aprender com você. Papai te ama.

Aos meus pais, Helemilton Dias de Oliveira e Marlene Grossi Resende de Oliveira, o amor e respeito que sinto por vocês não cabem em palavras grafadas nessa folha. Obrigado pelo estímulo e amor incondicional. 


\section{Agradecimento Especial}

Ao meu orientador Prof Dr. Luiz Antonio Salata. Por ter me propiciado a honra de ser seu orientado, me conduzido nos primeiros passos da vida científica sempre com paciência e sabedoria. Deixo Ribeirão Preto impregnado de respeito e admiração pela sua capacidade. Minha sincera gratidão. 


\section{Agradecimentos}

À Deus, por sempre abrir portas e apontar caminhos quando não vejo saídas.

À minha Irmã, Izabella Grossi de Oliveira, pelo carinho que sempre me faz sentir acolhido e "em casa".

Aos meus sogros Manoel e Nilce. Obrigado pelo carinho e ajuda inestimável à minha família nos períodos de minha ausência.

À minha "dupla" de mestrado, Antônio Azoubel Antunes, pela solicitude em me ajudar sempre que precisei. Sua amizade tornou o trajeto muito mais fácil.

Aos meus colegas de mestrado que se tornaram amigos queridos: André Pepato, Emanuela Ferraz, Fernando Pando. Em especial aqueles que foram minha família em Ribeirão Preto, inibindo os poucos momentos de tristeza e potencializando os inúmeros momentos de felicidade: Darklilson Santos, Marcus Breda Jr. e Willian Moraes.

Ao Dr Omar Gabriel da Silva Filho, pela capacidade sublime e paradoxal de ensinar com grandiosidade e simplicidade. Obrigado por me inspirar a buscar sempre o melhor de mim.

Aos professores: Dr. Alexandre Elias Trivelatto, Dr. Adalberto Rosa, Dr. Cássio Edvard Sverzut, Dr. Márcio Belotti, Paulo Tambasco, Dr. Samuel Porfírio Xavier pelos ensinamentos transmitidos. 
Ao Professor titular Valdemar Mallet da Rocha Barros, pelo tratamento humano e paternal com seus alunos, muito obrigado pelos ensinamentos, conversas e conselhos.

Aos meus companheiros de formação cirúrgica com quem aprendí $e$ continuo aprendendo Gabriel Ramalho Ferreira, Leonardo Perez Faverani, Rafael Augusto Ferreira e Leandro Carrasco. Obrigado pela amizade e confiança.

Aos funcionários da faculdade de odontologia de Ribeirão Preto- USP. Em especial ao Aldo, Adriana, Dulce, Isabel, Regiane, Se6astião e Tati, sempre solícitos e igualmente eficientes.

À Faculdade de Odontologia de Ribeirão Preto-USP. Pela estrutura oferecida à pós-graduação, permitindo o desenvolvimento de pesquisas de reconhecimento mundial.

A todos que de alguma forma contribuíram para a minha formação ou para a elaboração deste trabalho. 


\section{RESUMO}

Grossi-Oliveira, G.A. Efeito da hidrofilia da superfície de titânio na estabilidade do implante em defeitos ósseos marginais em mandíbula de cães. 2012. $74 f$. Dissertação (Mestrado) - Faculdade de Odontologia de Ribeirão Preto, Universidade de São Paulo. Ribeirão Preto 2012.

INTRODUÇÃO: A qualidade da interface osso-implante pode ser influenciada diretamente por aspectos inerentes ao tratamento da superfície do titânio e determina a forma que as células interagem, aderem e se fixam a ela, podendo potencializar e encurtar o tempo de osseointegração. Este estudo propôs-se a analisar alterações na osseointegração produzidas pela hidrofibilidade das superfícies dos implantes Neoss $\AA_{\text {. }}$.

MATERIAIS E MÉTODOS: Foram utilizados 6 cães da raça labrador e instalados 44 implantes Neoss ${ }^{\circledR}$ bilateralmente na mandíbula com defeitos ósseos padronizados na região coronal: 22 implantes apresentavam superfície ProActive (hidrofílica) e outros 22 implantes eram de superfície Bimodal (hidrofóbica). Foram avaliados a resposta biológica nos períodos de uma semana e quatro semanas de osseointegração, utilizando parâmetros histológicos, histomorfométricos, fluorescência e de estabilidade mecânica aferido pelo método de análise de frequência de ressonância (RFA). As superfícies também foram submetidas à análise topográfica por interferometria óptica e quanto a propriedade de hidrofibilidade.

RESULTADOS: Nos testes topográficos, a superfície ProActive apresentou valor de $\mathrm{Sa}$ de $0,4 \mu \mathrm{m}$ contra $\mathrm{Sa}$ de $0,8 \mu \mathrm{m}$ da superfície Bimodal, sugerindo menor rugosidade da superfície hidrofílica. A umectibillidade da superfície foi maior no grupo ProActive, exibindo valores de ângulos de contato de $27,2^{\circ}$ contra $67,2^{\circ}$ da superfície Bimodal. Ambas as superfícies apresentaram valores semelhantes nos períodos de uma e quatro semanas no que diz respeito à estabilidade mecânica do implante, aferidos com o RFA e nos parâmetros histomorfométricos em relação deposição óssea ao seu redor 
CONCLUSÕES: 1) A superfície ProActive apresentou valores menores de rugosidade e aumento da umectibilidade em relação aos implantes com superfície Bimodal. 2) A superfície ProActive utilizada no presente estudo não favoreceu os eventos de osseointegração nas condições períodos de 1 e 4 semanas avaliados. 3) Após 4 semanas de osseointegração, ocorreu aumento da estabilidade dos implantes instalados sem haver diferença entre as superfícies ProActive e Bimodal. 4) A estabilidade dos implantes, avaliados por meio do RFA, aumentou gradativamente durante a osseointegração, sem haver diferença entre as superfícies testadas.

Palavras chave: implantes dentários, superfície de implante; hidrofílico 


\section{ABSTRACT}

Grossi-Oliveira, G.A. Effects of hydrophilic surface on dental implants osseointegration in circumferential bone defects: an experimental study in dogs. 2012. 74f. Thesis (Master's degree) - Dental School of Ribeirão Preto, São Paulo State University.. Ribeirão Preto, 2012.

INTRODUCTION: The quality of the bone-implant interface can be directly influenced by factors inherent to titanium surface treatment which determines cells interaction and adherence to shortening the time for osseointegration. This study aimed to assess changes on osseointegration produced by the hidrophibility of Neoss $\AA$ implants surfaces.

MATERIALS AND METHODS: Six labrador dogs were used and 44 Neoss $\circledast$ implants bilaterally installed in the mandible (ProActive ${ }^{\mathrm{TM}}$ with hydrophilic surface) and (Bimodal ${ }^{\mathrm{TM}}$ hydrophobic surface), in standardized bone defects in the coronal region. The biological responses in one and four weeks of osseointegration were evaluated using histological, histomorphometric, fluorescence analysis and mechanical stability measured by Resonance Frequency Analysis (RFA). The surfaces were also subjected to topographic analysis by optical interferometry and hydrophobicity by wettability analysis.

RESULTS: The topographic surfaces test showed value of 0.4 micrometers for ProActive implants, against 0.8 micrometers for Bimodal implants, suggesting less hydrophilic surface roughness in the former $(p \leq 0.05)$. The wettability values were higher in ProActive surface, with contact angles of $27.2^{\circ}$ versus $67.2^{\circ}$ of the Bimodal surface $(p \leq 0.05)$. Both implant surfaces exhibited similar mechanical stability measured by RFA, as well as the histomorphometric parameters related to bone deposition onto the surfaces.

CONCLUSIONS: 1) The ProActive surface showed lower roughness values and increased wettability compared to Bimodal surface. 2) The ProActive surface did not favor osseointegration at 1 and 4 weeks. 3) After 4 weeks of osseointegration the implants increased in stability, with no statistical differences between Bimodal and ProActive surfaces

Key words: Dental implant, Implant surface, hydrofilic 


\section{SUMÁRIO}

1. JUSTIFICATIVA 1

2. INTRODUÇÃO 4

$\begin{array}{lll}2.1 & \text { A OSSEOINTEGRAÇÃO } & 8\end{array}$

2.2 TRATAMENTO DA SUPERFÍCIE 9

$\begin{array}{lll}\text { 3. PROPOSIÇÃO } & 16\end{array}$

$\begin{array}{lll}\text { 4. METODOLOGIA } & 18\end{array}$

$\begin{array}{lll}4.1 & \text { ANIMAIS } & 19\end{array}$

$\begin{array}{lll}4.2 & \text { DESENHO EXPERIMENTAL } & 19\end{array}$

$\begin{array}{lll}4.3 & \text { CIRURGIAS DE EXODONTIA } & 20\end{array}$

4.4 CIRURGIA DE IMPLANTAÇÃO 21

4.5 MENSURAÇÃO DA ESTABILIDADE DOS IMPLANTES 28

4.6 ANÁLISE DE FLUORESCÊNCIA 29

$\begin{array}{lll}4.7 & \text { EUTANÁSIA DOS ANIMAIS } & 29\end{array}$

$\begin{array}{lllll} & \text { PROCESSAMENTO HISTOLÓGICO E } & \text { ANÁLISE } & \\ 4.8 & \text { HISTOMÉTRICA } & & \end{array}$

4.9 MOLHABILIDADE DA SUPERFÍCIE 31

$\begin{array}{lll}4.10 & \text { TOPOGRAFIA } & 33\end{array}$

$5 \quad$ RESULTADOS $\quad 35$

6 DISCUSSÃO $\quad 54$

7 CONCLUSÕES $\quad 64$

8 REFERÊNCIAS $\quad 66$

$\begin{array}{lll}.9 & \text { ANEXOS } & 73\end{array}$ 
Justificativa 


\section{JUSTIFICATIVA}

A reabilitação com implantes osseointegráveis é considerada um procedimento com alta previsibilidade desde os achados de Branemark nas décadas de 50 e 60. Por ser material biocompatível, o titânio permite a migração de osteoblastos em sua superfície e deposição de matriz óssea ao seu redor. Após a instalação de implante no sítio receptor, ocorre uma cascata de eventos biológicos que se inicia com a interação da superfície do implante com água, íons e diferentes biomoléculas. A natureza dessa interação determina como as células e os tecidos irão responder ao processo de osseointegração (CARLSSON et al., 1989; DEE et al., 1996; LAVOS-VALERETO et al., 2002).

Predecki (1972) observou aumento da velocidade de formação óssea e estabilidade mecânica em superfícies irregulares de titânio. Desde então, a superfície do implante foi reconhecida como um fator modulador da resposta celular e diversos estudos dedicados à otimizar sua interação com os tecidos e favorecer os eventos iniciais da reparação óssea e da regeneração epitelial (GUEHENNEC et al., 2007; WENNERBER e ALBREKTSSON, 2009 e 2010; EHRENFEST et al., 2010).

O propósito da modificação biomecânica da superfície é imobilizar proteínas, enzimas e peptídeos sobre a superfície do implante com o objetivo de induzir a resposta de células e tecidos específicos, levando a um controle das moléculas liberadas na interface osso-implante (ANSELME et al., 2000).

Alterações da topografia por métodos de adição (plasma spray de titânio) e subtração (ataque ácido, bombardeamento com partículas e anodização) foram 
propostas como objetivo de aumentar a área e criar microtexturas na superfície. Tais alterações são capazes de alterar a direção da formação óssea. Enquanto nas superfícies usinadas a osseointegração ocorre por aposição óssea ocorrendo do osso do sítio receptor em direção ao implante. Nas superfícies tratadas ocorre nos dois sentidos, ou seja, além da formação ocorrer a partir da parede óssea em direção ao implante, também ocorre o povoamento de células da linhagem osteoblásticas da superfície do titânio e inicio da formação óssea do implante em direção ao osso. DAVIES (1998) deu o nome de osteogênese de contato para descrever esse fenômeno.

Entre todas as respostas celulares, a adesão celular é considerada a resposta mais importante por ser o início da sequencia biológica da formação óssea (CHEROUDI, et al.1988). De acordo com Schwartz \& Boyan (1994), para que ocorra a formação de tecido ósseo na superfície do implante, é necessário que haja o recrutamento e a proliferação de células precursoras de osteoblastos, as quais se diferenciem em osteoblastos e produzam matriz extracelular não mineralizada, que será subseqüentemente calcificada. Tais eventos sofrem grande influência das propriedades da superfície dos implantes de Ti, tais como, a composição química, energia de superfície e a textura da superfície, uma combinação entre topografia e rugosidade.

A hidrofibilidade do titânio talvez seja a mais recente mudança proposta. Surgiu com o intuito de melhorar a interação entre essa superfície e o sangue presente no sítio de instalação, dessa maneira, haveria um aumento de deposição de proteínas ao redor do implante, fator que permite o início precoce da osteogênese, aumentando também a área de contato entre osso e implante. 
Alterações químicas (Exposição à radiação ultra-violeta, imersão em soluções isotônicas de $\mathrm{NaCl}$ e eliminação de carbono da superfície) e físicas (aumento da rugosidade) do titânio têm sido relatadas como responsáveis pela quebra da tensão superficial dos fluidos (FERGUSSON et al., 2006; HYRAKAWA et al. 2012)

Evidências de estudos in vitro comprovam que o fenótipo osteoblástico, que é caracterizado pela produção de osteocalcina e osteprotegerina, é estimulado quando essas células são cultivadas em substratos hidrofílicos e com topografia micro-estruturada de titânio. A molhabilidade de superfície rugosa regula a produção de fator de crescimento endotelial vascular (VEGF) para promover osseointegração (OLIVARES-NAVARRETE et al., 2010). Em um estudo experimental em mandíbula de cães, BORNSTEIN et al. (2008) compararam superfícies do mesmo sistema de implantes (sandblasted and acid-etched SLA), mas com aumentada hidrofilibilidade no grupo teste. Comparado ao implante convencional, o grupo teste exibiu maior contato ósseo em 2 semanas após implantação. Em um estudo em humanos, DIGIDI et al. (2009) reportaram melhor contato ósseo em pacientes em 4 semanas com implantes microestruturados e mais hidrofílicos comparados aos convencionais produzidos pelo método SLA.

Assim, propriedades de superfície tais como a hidrofilia teriam a capacidade de induzir uma reposta osteoblástica mais eficiente, o que aumentaria o contato ósseo entre o osso e o implante e diminuiria o período necessário para a osseointegração (EHRENFEST et al., 2010; WENNERBERG et al., 2009), especialmente em procedimentos de implantes imediatos com carga funcional 
precoce. A estabilidade do implante deve ser atribuída a dois eventos distintos: a estabilidade primária, que responde pelo travamento inicial do implante durante sua instalação e a estabilidade secundária obtida pelos eventos biológicos e celulares de neoformação óssea ao redor da superfície do implante (SENNERBY et al., 1998).

As modificações que levam ao material adquirir propriedade hidrofílica não estão completamente claras na literatura. Métodos como a remoção da quantidade de carbono da superfície do implante com manutenção deste implante imerso em uma solução isotônica de $\mathrm{NaCl}$ são citados como responsável pelo aumento da interatividade do implante com os líquidos (RUPP et al., 2006; DONOS et al., 2011).

Tendo em vista a notoriedade da importância da topografia e propriedades químicas das superfícies de implantes adquiridas nos últimos anos, um grande número de superfícies foram propostas por diferentes empresas. A hidrofilia, sagrou-se como uma alteração relevante baseada em resultados otimistas de um número restrito de estudos in vivo e in vitro utilizando a superfície SLAactive, porém, para que seja possível tirar conclusões a respeito da resposta óssea induzida pela propriedade hidrofílica de diferentes sistemas de implante, se faz necessário avaliações qualitativas da superfície produzida e correlacioná-las com a resposta biológica observada individualmente.

Atualmente, os trabalhos envolvendo a análise da interface durante a osseointegração deste tipo de superfície abordam basicamente torque de remoção (FERGSSON et al., 2006), taxas de sucesso (GANELES et al., 2008), análise de frequência de ressonância (OATES et al., 2009), análise 
histomorfométrica (SCHWARZ et al., 2007; LAl et al., 2009; LANG et al., 2011, SCHLEGEL et al., 2011) e recentemente, teste de expressão gênica in vitro (WALL et al, 2009; DONOS et al., 2011) sendo estes parâmetros aplicados de maneira isolada. Apesar de resultados favoráveis, não foi reproduzido nenhum modelo que compare a estabilidade, contato entre osso e superfícies hidrofílicas de implantes por meio de RFA em conjunto com a avaliação histométrica e histológica, bem como sobre a propriedade topográfica e da hidrofibilidade da superfície. 


\section{INTRODUÇÃO}

\subsection{A OSSEOINTEGRAÇÃO}

A busca pela reposição de elementos dentários iniciou em civilizações antigas. Indícios históricos demonstram a tentativa de repor o elemento dentário perdido com próteses em marfim, pedra ou mesmo órgãos dentários extraídos de animais ou do próprio homem. Historicamente, as tentativas de se obter a substituição do elemento dentário perdido com ancoragem óssea foram aplicadas de maneira empírica, sem nenhuma ou pouca chance de sucesso (SPIEKERMANN, 2000).

Foi a partir da década de 50, após observações do professor Per-Ingvar Branemark, iniciou-se o desenvolvimento da implantodontia moderna. Branemark realizava estudos experimentais sobre microcirculação e reparação óssea. Com o objetivo de observar estes fenômenos in vivo à luz da microscopia óptica, câmaras de observação feitas de tântalo ou titânio eram instaladas nas tíbias de coelhos. Após o término das observações, ao remover as câmaras, ele observou que as câmaras de tântalo eram removidas com facilidade, fato que não ocorria quando o material utilizado era o titânio. Ao buscar a resposta para este fenômeno, Branemark descobriu a bioinércia do titânio ao tecido ósseo e a deposição de osso sobre sua superfície e incorporação deste metal ao osso vivo. Este fenômeno foi chamado de osseointegração.

Diversos estudos experimentais foram desenvolvidos subsequentemente objetivando o suporte de estruturas protéticas. A primeira resolução protética proposta com o advento dos implantes osseointegráveis foi a reabilitação de pacientes edêntulos, particularmente em mandíbula, onde a estabilidade das 
próteses totais é comprometida pela ação da musculatura bucal. Nesta ocasião os implantes utilizados eram cilíndricos e usinados, desta maneira, apresentavam superfícies lisas. Em 77, Branemark publicou resultados promissores e com alta porcentagem de sucesso após 10 anos de experiência com este tipo de reabilitação (BRANEMARK et al., 1977).

A consolidação da reabilitação com implantes osseointegráveis deu início a inúmeros trabalhos experimentais com o objetivo de ampliar as possibilidades de resoluções protéticas frente às perdas dentárias. Em pouco tempo reabilitações unitárias passaram a ser praticadas com grande previsibilidade funcional e estética, desenhos dos implantes foram alterados conforme aumentava a necessidade de reabilitação nos locais onde a qualidade óssea dificultava a estabilidade inicial.

\subsection{TRATAMENTO DA SUPERFÍCIE}

As buscas constantes de melhorias do processo de osseointegração transcenderam o formato do implante. Imediatamente após a instalação do implante, é iniciada a precipitação de fibrina sobre sua superfície e a esta rede de fibrina, inicia-se a agregação plaquetária que libera fatores de crescimento estimulando o recrutamento e proliferação de células de linhagem osteoblástica e posteriormente diferenciação destas em osteoblastos que iniciam a deposição de matriz celular não mineralizada, que será subsequentemente calcificada.

Durante a usinagem do implante de titânio, é gerada uma camada superficial não uniforme, oxidada e contaminada, a qual se encontra geralmente deformada plasticamente e com tensões internas. Essa superfície nativa não é apropriada para aplicações biomédicas havendo a necessidade de realização de algum tipo de 
tratamento superficial para melhorar suas propriedades. $O$ tratamento das superfícies de titânio tem o objetivo de melhorar e acelerar os eventos celulares responsáveis pela deposição óssea na superfície do implante (LIU et al., 2004).

\section{Topografia}

A topografia do implante representa a rugosidade e orientação das irregularidades presentes no titânio, podendo variar em escalas de milímetros (mm), micrometros $(\mu \mathrm{m})$ e nanômetros $(\mathrm{nm})$. Predecki et al. em 1972 relatou que o aumento da rugosidade da superfície do implante poderia favorecer a estabilidade secundária, condição estabelecida durante a proliferação óssea em íntimo contato com a superfície do titânio. A melhora da interface osso-implante em superfícies rugosas tem sido demonstrada desde então por estudos experimentais (ALBREKTSON et al., 1981). A rugosidade pode ser conferida ao implante por métodos de adição ou subtração. Nos métodos de adição, é aplicado um recobrimento à superfície do implante que pode ser do mesmo material do corpo do implante ou não. Nos métodos de subtração, uma camada da superfície do implante é removida.

Com o intuito de padronizar a comunicação sobre a quantificação das irregularidades, Wennemberg et al., em 2009 classificou as superfícies de acordo com a rugosidade topográfica que apresentavam. As superfícies lisas possuem Sa $>0,5 \mu \mathrm{m}$, superfícies minimamente rugosas Sa de 0,5 a $1 \mu \mathrm{m}$, superfícies moderadamente rugosas Sa de 1 a $2 \mu \mathrm{m}$ e superfícies rugosas Sa maior que $2 \mu \mathrm{m}$. 


\section{Macrotopografia}

A macrotopografia abrange rugosidades realizadas em escala milimétrica e pode ser divididas em dois grupos de acordo com o método empregado: a adição de material (Plasma-spray de titânio ou hidroxiapatita) ou subtração (Jateamento de partículas) Atualmente, os métodos de adição encontram-se em desuso.

\section{Plasma spray de titânio}

Este método de tratamento de superfície consiste no jateamento de pó de titânio em uma pistola de plasma, em alta temperatura, de forma que as partículas de titânio sejam projetadas e fundidas sobre a superfície do implante, formando um filme de aproximadamente $50 \mu \mathrm{m}$ de espessura e rugosidade superior à $2 \mu \mathrm{m}$. Apesar de mostrarem bons resultados à longo prazo, principalmente quando comparados com superfícies usinadas, caíram em desuso. Existe um consenso que superfícies moderadamente rugosas, com rugosidades entre 0,5 a $2 \mu \mathrm{m}$, alteram a resposta tecidual de maneira mais efetiva (BUSER et al, 1991; ONG et al., 2004)

\section{Plasma Spray de Hidroxiapatita (HA)}

A hidroxiapatita (HA) é um material bioativo com promissor efeito osseocondutor. Baseados nessas propriedades, o recobrimento com HA foi utilizado em implantes osseointegráveis desde meados da década de 80. Apesar do tratamento de pacientes com implantes recobertos com HA estar bem estabelecido, sua previsibilidade clínica ainda continua controversa (LEE et al., 2000; ONG et al. 2004).

De acordo com levantamento feito por Biesbrock e Edgerton em 1995, estudos clínicos sugerem que os implantes recobertos por HA possuem taxa de 
sobrevivência pequena em curto prazo quando comparada à superfície de titânio, tendo como principais problemas a facilitação da adesão bacteriana, fratura do recobrimento e dissolução da HA. Atualmente a superfície plasma spray de hidroxiapatita está em desuso devido seu alto custo de fabricação e por estudos in vivo terem demonstrado o destacamento da camada de hidroxiapatita

\section{Jateamento de partículas}

O jateamento é um método de tratamento de superfície por subtração, onde o implante é bombardeado por partículas de tamanhos variados de materiais que devem ser quimicamente estável e biocompatível, tais como silício, óxido de alumínio $\left(\mathrm{Al}_{2} \mathrm{O}_{3}\right)$, óxido de titânio $\left(\mathrm{TiO}_{2}\right)$, fosfato de cálcio $(\mathrm{CaP})$ e vidro. Desta maneira, cria-se por meio de abrasão, uma superfície com ranhuras irregulares que podem variar de acordo com o tamanho e forma das partículas e também pelas condições do jateamento (pressão, distância do bico do jato à superfície do implante, tempo de jateamento). Este método produz superfície com rugosidade que podem variar de 1,2 e 2,2 $\mu$ m (APARICIO et al., 2003; IVANOFF et al., 2001).

\section{Microtopografia}

Alterações da superfície em escala microtopográfica é comprovadamente um fator que auxilia na melhora da interface osso-implante. Implantes com superfícies moderadamente rugosas possuem resultados melhores quando comparados com as demais, sendo que o aumento da rugosidade acima de $2 \mu \mathrm{m}$ pode acarretar resposta óssea prejudicada (WENNEMBERG et al., 2009). Atualmente encontra-se disponível no mercado implantes com topografias em escala nanométrica. A relevância destas estruturas ainda não foi consagrada e pouco se sabe sobre sua influência na resposta óssea. Estudos in vitro 
demonstraram influencia positiva desta caracterização na diferenciação osteoblástica (MEIRELLES et al., 2008).

\section{Ataque ácido}

O titânio é um material resistente à corrosão, no entanto alguns ácidos podem ser usados para criar porosidades removendo uma pequena quantidade de material, modificando assim a superfície.

O ataque ácido corresponde a um método de tratamento da superfície do titânio por subtração onde os implantes de titânio são imersos em ácidos (sulfúrico, clorídrico, nítrico, fluorídrico e combinações) e mantidos por intervalos de tempo determinado, criando pequenas rugosidades ou retenções na superfície, O tempo de aplicação do ácido e sua temperatura, juntamente com a concentração, determinarão a profundidade das rugosidades criadas. A profundidade das retenções criadas pelo ataque ácido é menor que as formadas pelo jateamento, sendo chamadas de microretenções, as quais podem medir de 0,5 à $3 \mu \mathrm{m}$ (WENNEMBERG et al., 1995)

Atualmente, muitos fabricantes utilizam o ataque ácido em combinação com outra técnica de tratamento de superfície, obtendo assim superfícies híbridas com associação de macro e microretenções.

\section{Oxidação}

Por meio da oxidação, é possível aumentar a espessura da camada de óxido de titânio. O processo consiste em colocar o implante como o ânodo de uma célula galvânica com um eletrólito adequado. Depois de passar uma corrente elétrica 
através da célula galvânica, ocorre o espessamento da superfície de óxido nativa do implante com cerca de $5 \mathrm{~nm}$, podendo atingir $1 \mu \mathrm{m}$ ou mais.

Quando ácidos fortes são utilizados em uma solução eletrolítica, a camada óxida será dissolvida ao longo das linhas de convecção da corrente, sendo novamente formadas em outras regiões do material. Essa dissolução acarreta a formação de micro e nano poros na superfície do titânio (GUEHENNEC et al., 2007).

\section{Ablasão à laser}

A preparação da superfície por condicionamento com feixes de laser cria estrias que orientam a adesão celular de células osteoprogenitoras e inibem a migração e o crescimento de fibroblastos (SOBOYEJO et al., 2002) este processo resulta na criação de microestruturas na superfície do implante com aumento na dureza, resistência à corrosão e espessamento da camada do óxido de titânio. (BEREZNAl et al., 2003)

\section{Energia de superfície}

A hidrofibilidade de uma superfície diz respeito sobre a capacidade desta em interagir com os fluídos. Transpondo para situação clínica, representa o aumento do contato entre o sangue e a superfície do titânio. Desta maneira, contribui para a organização da camada de proteínas adsorvidas na superfície e recrutamento celular sobre ela.

Importante ressaltar que a capacidade da superfície do titânio de atrair os fluídos independe da composição da liga de titânio utilizada em sua confecção, 
esta característica é determinada pela camada atômica mais externa do material. Essa caracterização atômica é responsável pela interação com o sangue e quebra da tensão superficial.

A função da umectibilidade da superfície dos implantes dentais não está completamente elucidada pela literatura. A escassez de estudos experimentais aliado à divergência de metodologia entre os modelos experimentais geram dúvidas sobre a efetividade deste tipo de tratamento É necessário que haja investimento em novos estudos para avaliação e padronização dos testes a fim de avaliar a influência da superfície hidrofílica sobre a osseointegração, taxas de sucesso e longevidade. 
Proposição 


\section{PROPOSIÇÃO}

Os objetivos deste estudo foram comparar a influência da superfície nos eventos precoces da osseointegração, considerando: 1) as características topográficas e de hidrofibilidade dos implantes Neoss ${ }^{\circledR}$ com superfície hidrofílica (ProActive ${ }^{\circledR}$ ) e convencional (Bimodal@); 2) investigar por meio de parâmetros histológicos, histomorfométricos e fluorescência, a dinâmica do processo de osseointegração em implantes hidrofílicos em regiões onde existe espaço entre o implante e o leito receptor e comparar o processo de osteogênese ao redor destes implantes com a superfície Bimodal; 3) avaliar a estabilidade adquirida após 4 semanas de osseointegração em implantes de superfícies hidrofílica e Bimodal por meio de análise de frequência de ressonância (RFA). 
Metodologia 


\section{METODOLOGIA}

\subsection{ANIMAIS}

Para este estudo foram utilizados 06 cães jovens, da raça labrador, pesando entre 20 e 30 quilos. O presente estudo foi aprovado pela Comissão de Ética no Uso de Animais (CEUA) da Universidade de São Paulo, protocolo número 10.1.973.53.1. Os animais permaneceram em quarentena para aplicação de vacina antirrábica e tríplice, vermífugos e vitaminas. Os animais foram mantidos em baias individuais no biotério da FORP-USP no período pré e pós-operatório, sob adequados cuidados veterinários, com livre acesso à água e suporte nutricional padrão de laboratório durante todo o período de experimentação.

\subsection{DESENHO EXPERIMENTAL}

A fase cirúrgica do experimento foi realizada em três etapas: a primeira consistiu na exodontia bilateral dos dentes pré-molares e primeiro molar mandibulares. Três meses após as exodontias foram instalados 4 implantes Neoss (Neoss Ltd, Harrogate, UK), sendo 2 com superfície Bimodal® (convencional) como controle e 2 com superfície ProActive® (hidrofílica), distribuídos alternadamente sobre 0 rebordo alveolar mandibular unilateralmente. A terceira fase cirúrgica foi realizada três semanas após a segunda, com instalação de implantes no lado contralateral, seguindo os mesmos passos cirúrgicos e critérios adotados na segunda fase. Os animais foram sacrificados 1 semana após a realização da terceira fase cirúrgica. Portanto, o processo de osseointegração dos implantes foram avaliados em 1 e 4 semanas. 


\subsection{CIRURGIAS DE EXODONTIA}

Todos os animais foram submetidos a cirurgias de exodontias bilaterais dos 4 pré-molares mandibulares. Para tanto, os animais foram pré-anestesiados por meio de injeção intramuscular de pré-anestésico Rompun® 2\% (Xilazina, Bayer HealthCare Pharmaceuticals $\AA^{\circledR}$, Berlin, Alemanha) na dosagem de $0,05 \mathrm{~mL} / \mathrm{kg} 30$ minutos antes do ato operatório. A seguir, por via endovenosa, foi realizada a anestesia geral com Thiopentax ${ }^{\circledR}$ 1\% (Thiopental sódico, Cristália Produtos químicos farmacêuticos LTDA., Itapira, SP), na dosagem de $1 \mathrm{~mL} / \mathrm{kg}$ (solução de $20 \mathrm{mg} / \mathrm{kg}$ diluído em $50 \mathrm{ml}$ de soro fisiológico estéril a 0,9\%). Durante todo o procedimento cirúrgico, os animais foram mantidos com solução isotônica de cloreto de sódio (Glicolabor Ind. Farm. Ltda., São Paulo, SP) a 0,9\% com 2,5\% de glicose. A anti-sepsia externa será realizada com PVPI tópico (polivinilpirrolidona, Rioquímica ${ }^{\circledR}$, Barretos, SP) e a anti-sepsia da cavidade bucal foi realizada com Cepacol ${ }^{\circledR}$ (cloreto de cetilpiridíneo a 50\%, Aventis Pharma Ltda., Suzano, SP) e água oxigenada 10v (Farmax ${ }^{\circledR}$, Divinópolis, MG). Após a colocação do campo cirúrgico esterilizado sobre o cão, mantendo-se apenas a cabeça exposta, foi realizada anestesia infiltrativa complementar bilateral na região dos pré-molares inferiores, utilizando-se $1,8 \mathrm{ml}$ de anestésico local do tipo mepivacaína a 2\% com noradrenalina 1:100.000 (Scandicaine, Septodont, Distribuidora DFL Ind. Com. Ltda., Rio de Janeiro, RJ). Em seguida foi realizada incisão intra-sulcular e descolamento de retalho mucoperiosteal bilateralmente. Os quatro pré-molares inferiores foram seccionados e extraídos com o emprego de fórceps e/ou elevadores sem danificar as paredes alveolares. Os tecidos 
foram reposicionados e suturados com fio Mononylon ${ }^{\circledR} 4-0$ (Ethicon ${ }^{\circledR}$, Johnson \& Johnson®, São José dos Campos, SP). Durante o período de recuperação da anestesia o animal foi mantido em sala própria de recuperação onde permaneceu por 24 horas e depois transferido para baias do canil do biotério da Faculdade de Odontologia de Ribeirão Preto - USP, onde permaneceu durante todo o período experimental. Os animais foram acompanhados durante um período de reparo alveolar de 12 semanas. Todas as cirurgias foram realizadas pelo mesmo cirurgião, dentro de padrões assépticos e com irrigação abundante com S.F. 0,9\% (Glicolabor Ind. Farm. Ltda., São Paulo, SP) para manutenção da vitalidade óssea. Os animais foram observados durante todo o período experimental e receberão o analgésico cloridrato de tramadol (Anangon ${ }^{\circledR}$ Laboratórios Biosintética Itda. - São Paulo - SP) que foi administrado por via endovenosa (Solução injetável de $50 \mathrm{mg}$ ), na dosagem de $3 \mathrm{mg} / \mathrm{kg}$ de peso do animal, uma vez ao dia durante 3 a 4 dias. A antibioticoterapia também foi instituída utilizando a suspensão de Pentabiótico Veterinário de Pequeno Porte (Fort Dodge ${ }^{\circledR}$, Agroline, Campo Grande, MS) na dose de $0,5 \mathrm{mg} / \mathrm{kg}$. Não houve quaisquer anormalidades, tais como mudanças de hábitos alimentares, inflamação ou supuração dos tecidos.

\subsection{CIRURGIAS DE IMPLANTAÇÃO}

As cirurgias de instalação dos implantes osseointegráveis foram realizadas em períodos de 12 semanas e 15 semanas após a cirurgia de extração (Figura 1). Cada cão foi submetido à inserção de quatro implantes osseointegráveis Neoss $^{\circledR}$ : 2 implantes controles com superfície Bimodal e 2 implantes com 
superfície ProActive, medindo $4.0 \mathrm{~mm} \times 11.0 \mathrm{~mm}$. Em dois cães, devido ao espaço disponível restrito, foram instalados apenas 3 implantes em cada hemimandíbula. Para que todas as variáveis sejam testadas em um mesmo animal e em diferentes quadrantes, cada hemi-arco mandibular recebeu um sistema de distribuição aleatória. Todos os procedimentos pré-operatórios de anestesia e anti-sepsia, assim como também os procedimentos cirúrgicos para obtenção de retalho mucoperiosteal foram os mesmos já descritos anteriormente. Após exposição do leito ósseo receptor, o preparo dos sítios ósseos para instalação dos implantes foi cirurgicamente padronizado e realizado sob copiosa irrigação com soro fisiológico estéril a 0,9\%, conforme recomendações do fabricante.

Utilizando brocas sequenciais de diâmetro de $2.0 \mathrm{~mm}$, uma piloto de 2 para $3 \mathrm{~mm}$ e finalmente broca de $3.15 \mathrm{~mm}$. Foram confeccionados quatros sítios implantares de $11.0 \mathrm{~mm}$ de profundidade na região dos pré-molares e primeiro molar. Logo em seguida, os implantes foram inseridos nos sítios recémpreparados. Neste mesmo tempo cirúrgico, foram confeccionados defeitos ósseos em forma de circunferências padronizados em redor dos implantes, utilizando broca trefina de $5.0 \mathrm{~mm}$ de diâmetro x 4.0 de profundidade (Figura 2). Esse defeito visa criar um espaço de $0.5 \mathrm{~mm}$ entre a superfície do implante e o rebordo alveolar na sua porção cervical. Após a colocação dos parafusos de cobertura, os retalhos foram reposicionados cuidadosamente e suturados com fio de sutura absorvível, de forma a cobrir completamente todos os implantes. 
Lado A

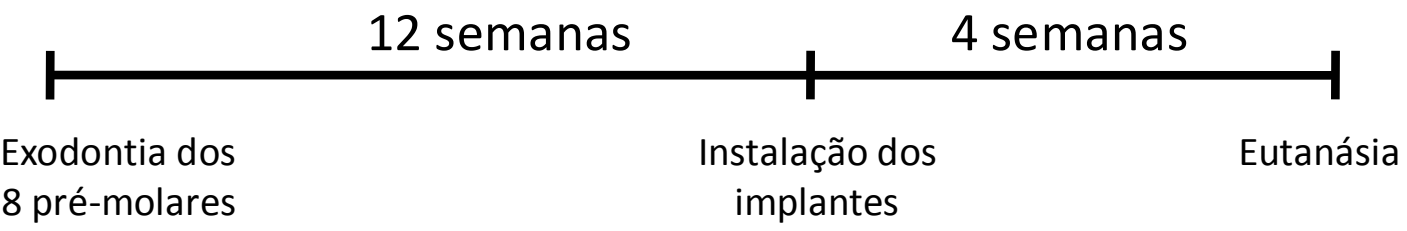

Lado B

15 semanas

1 semana

Instalação Eutanásia

dos

implantes

Figura 1 - Fluxograma dos experimentos. Os lados A e B representam as hemimandíbulas dos cães.

Todas as cirurgias foram realizadas pelo mesmo cirurgião, dentro de padrões assépticos e com suficiente refrigeração, para manutenção da vitalidade óssea. Os cuidados pós-operatórios com os animais foram os mesmos instituídos após a cirurgia de exodontia. 

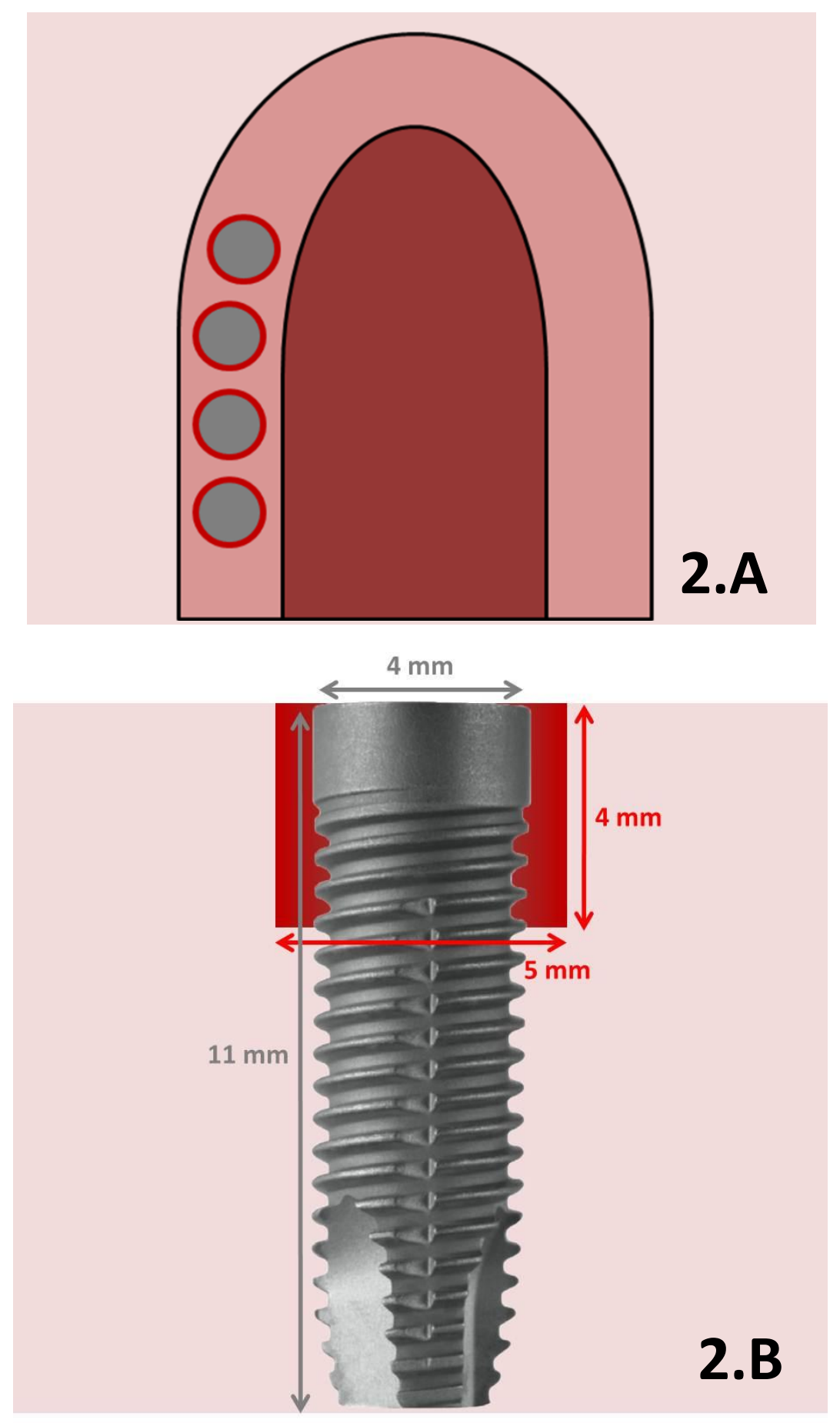

Figura 2 - Instalação dos implantes no rebordo alveolar edêntulo da mandíbula dos cães e criação dos defeitos ósseos circunferenciais com utilização de broca trefina após a instalação dos implantes. A) Vista Oclusal. B) Defeitos ósseos com a porção coronal do alvéolo apresentando $5.0 \mathrm{~mm}$ de diâmetro e $4.0 \mathrm{~mm}$ de profundidade. 


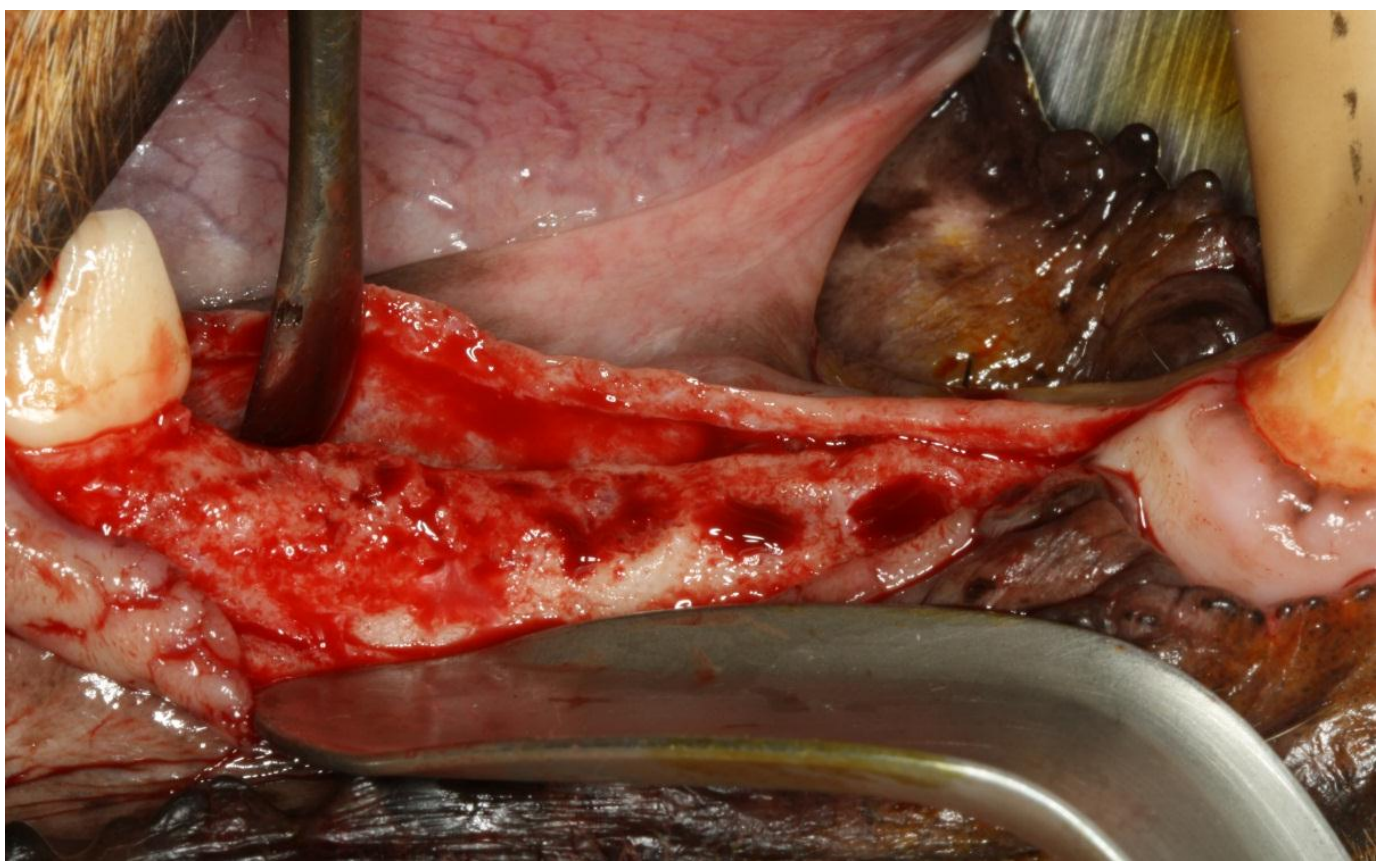

Figura 3- Descolamento mucoperiosteal e exposição da crista óssea

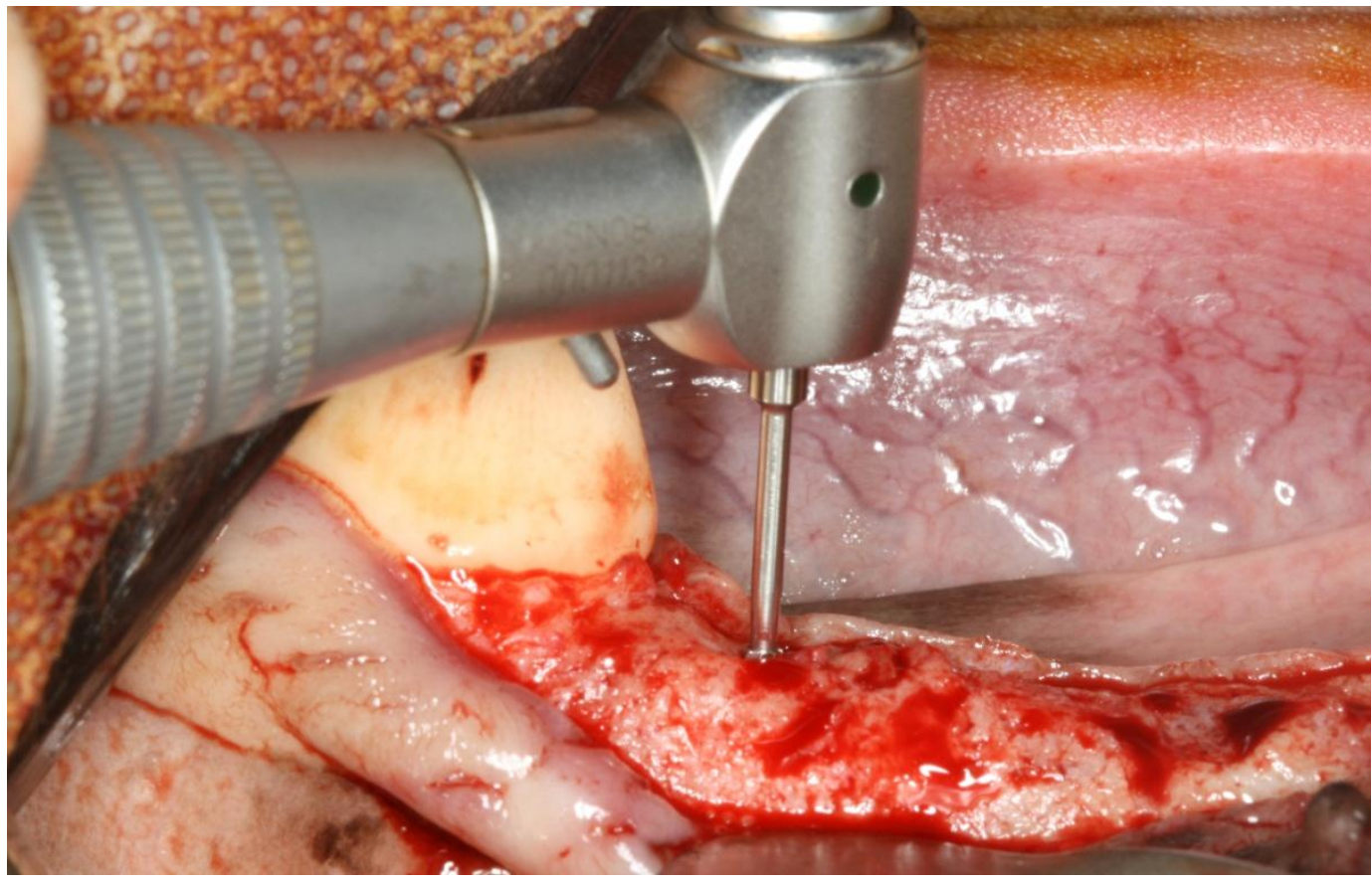

Figura 4 - Inicio do prepara do leito receptor para instalação dos implantes 


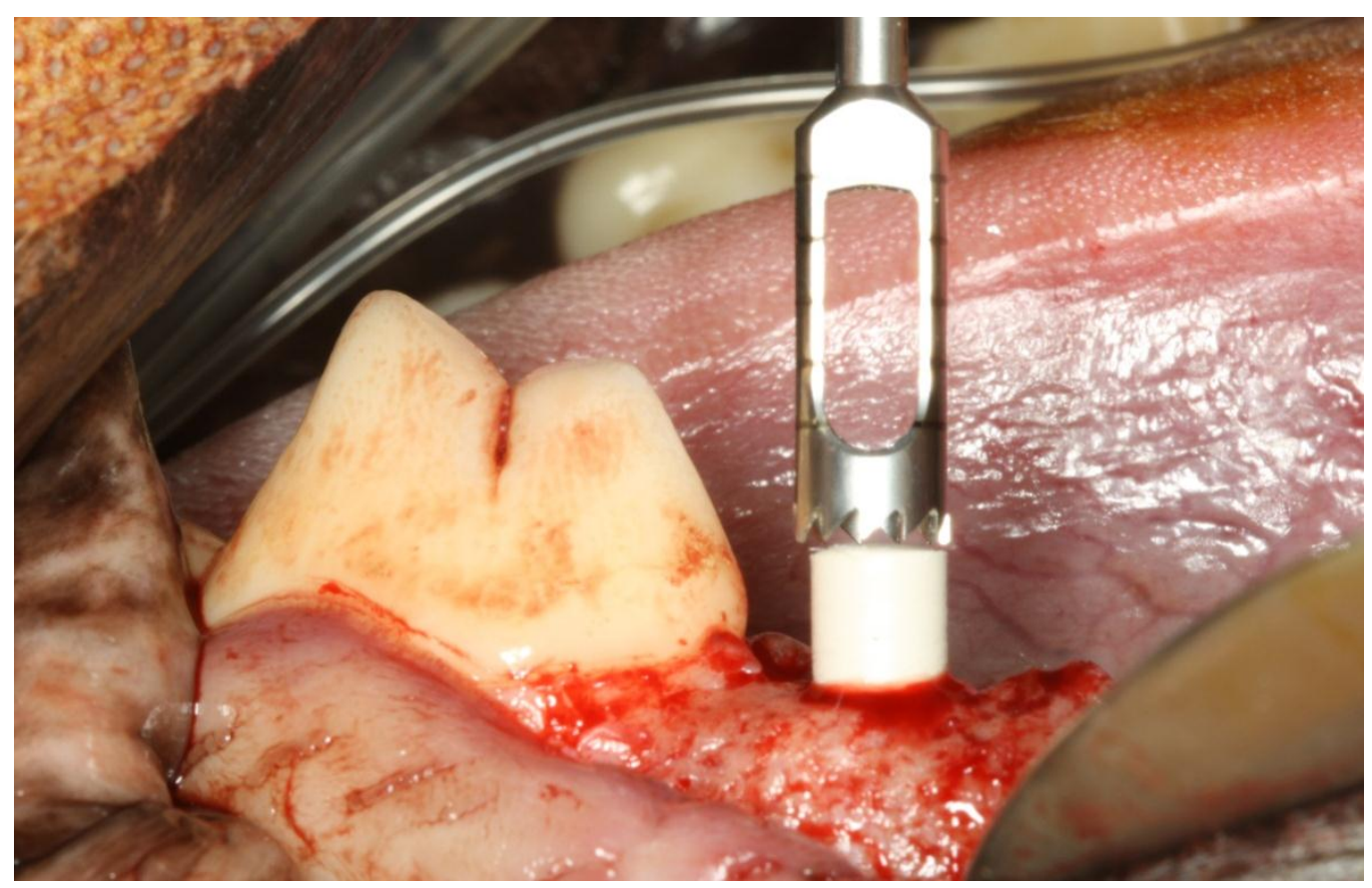

Figura 5 - Padronização dos defeitos ósseos com auxílio de trefinas e dispositivo confeccionado para esta finalidade.

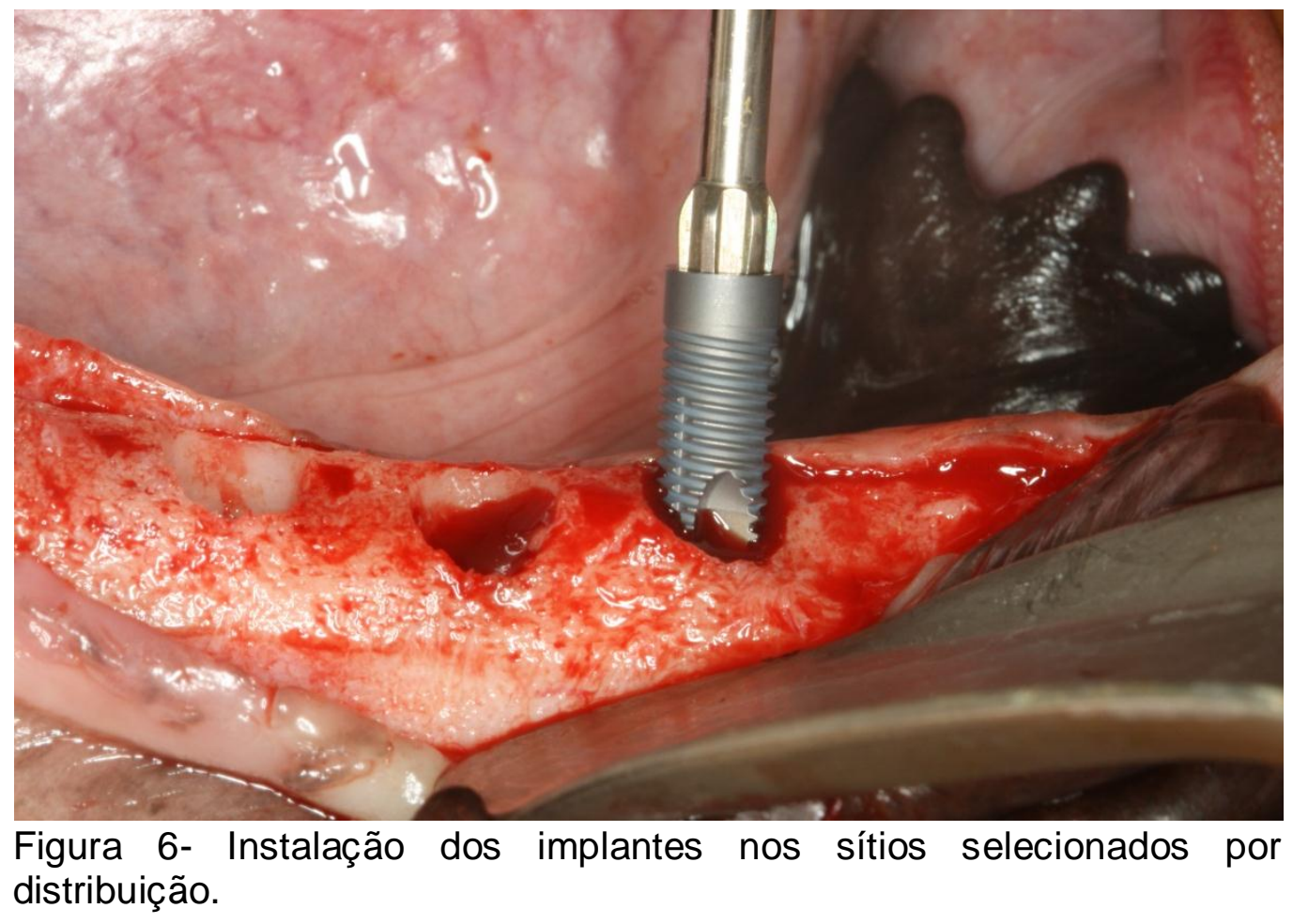




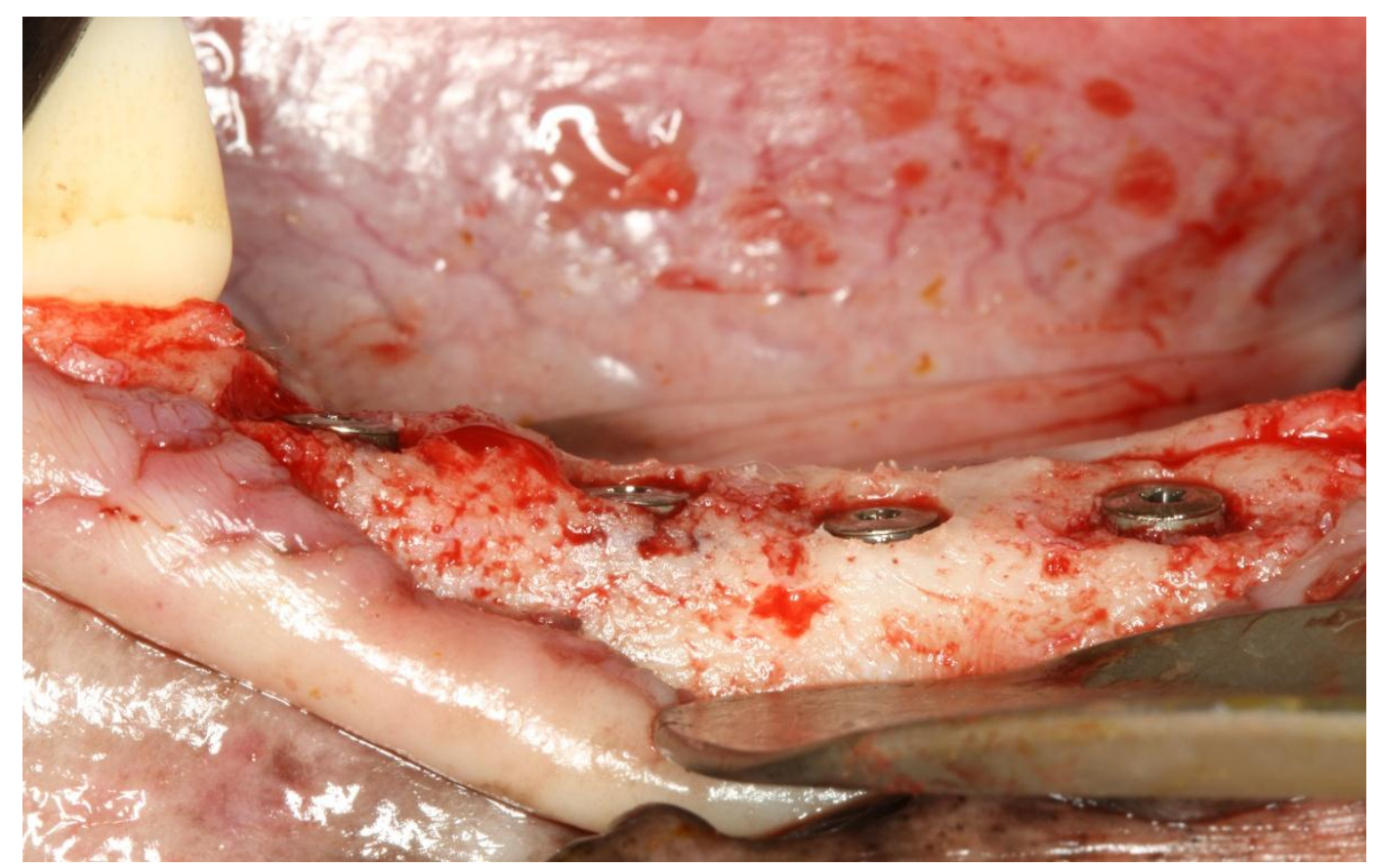

Figura 7 - Implantes instalados ao nível da crista óssea no sentido mésiodistal.

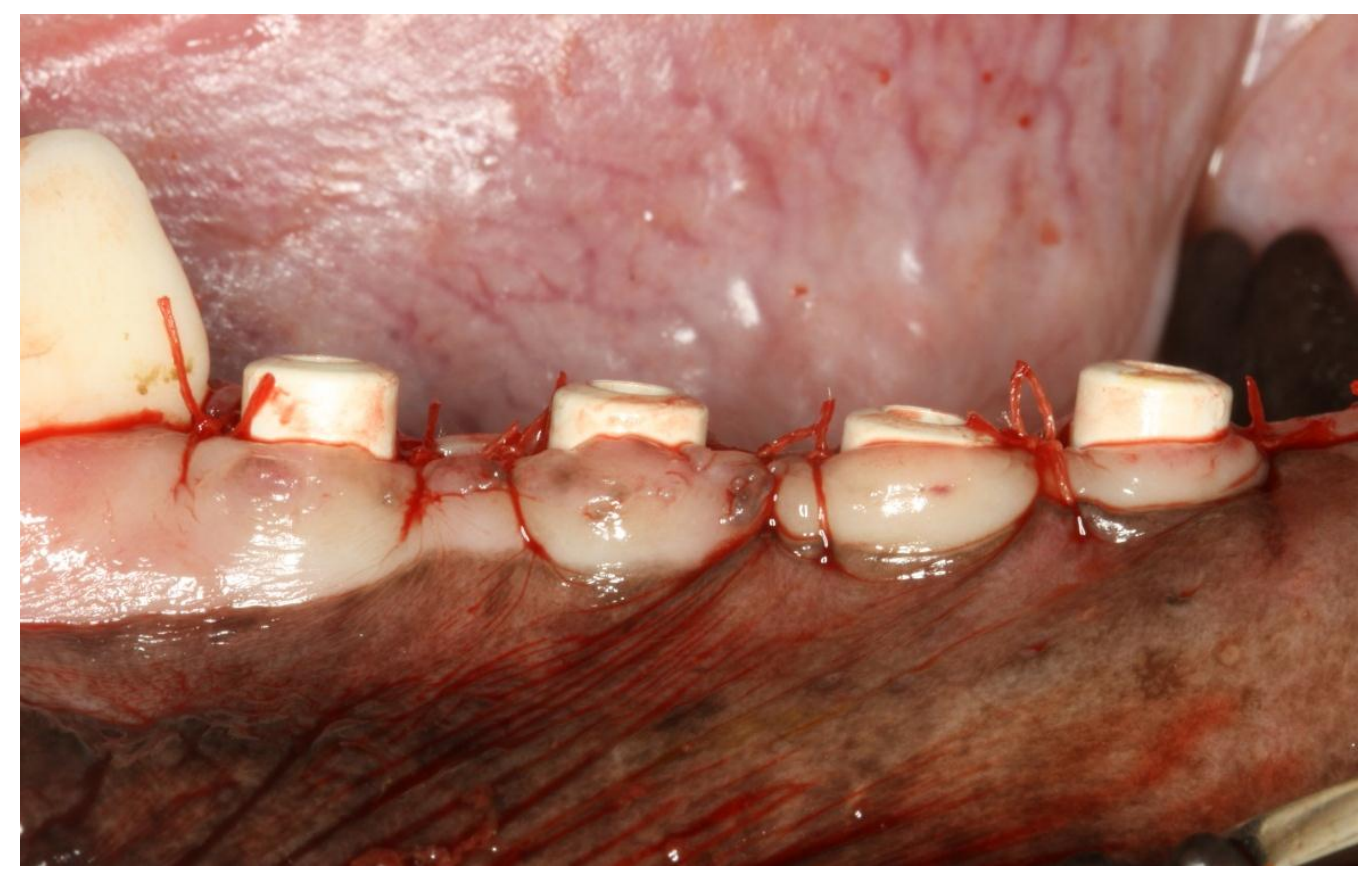

Figura 8 - Sutura do retalho com pontos interrompidos e cicatrizadores em posição. 


\subsection{MENSURAÇÃO DA ESTABILIDADE DOS IMPLANTES}

A estabilidade dos implantes foi medida por meio da análise de frequência de ressonância (RFA) do complexo osso-implante, utilizando Osstell Mentor ${ }^{\circledR}$ (Integration Diagnostics AB, Gotemburgo, Suécia), medida definida como quociente de estabilidade do implante (ISQ), cujos valores variam de 1 a 100 e quanto maior o valor, maior é a estabilidade. Conforme recomendação do fabricante, as medidas de estabilidade dos implantes foram realizadas nas direções vestíbulo-lingual e anteroposterior e calculada a média das duas medidas.

A avaliação foi realizada nos seis cães no momento da instalação dos implantes, previamente à instalação dos cicatrizadores, com o animal ainda anestesiado. No momento da eutanásia, uma nova avaliação da estabilidade dos implantes utilizando a RFA foi utilizada, para comparações entre 1 e 4 semanas de osseointegração dos implantes.

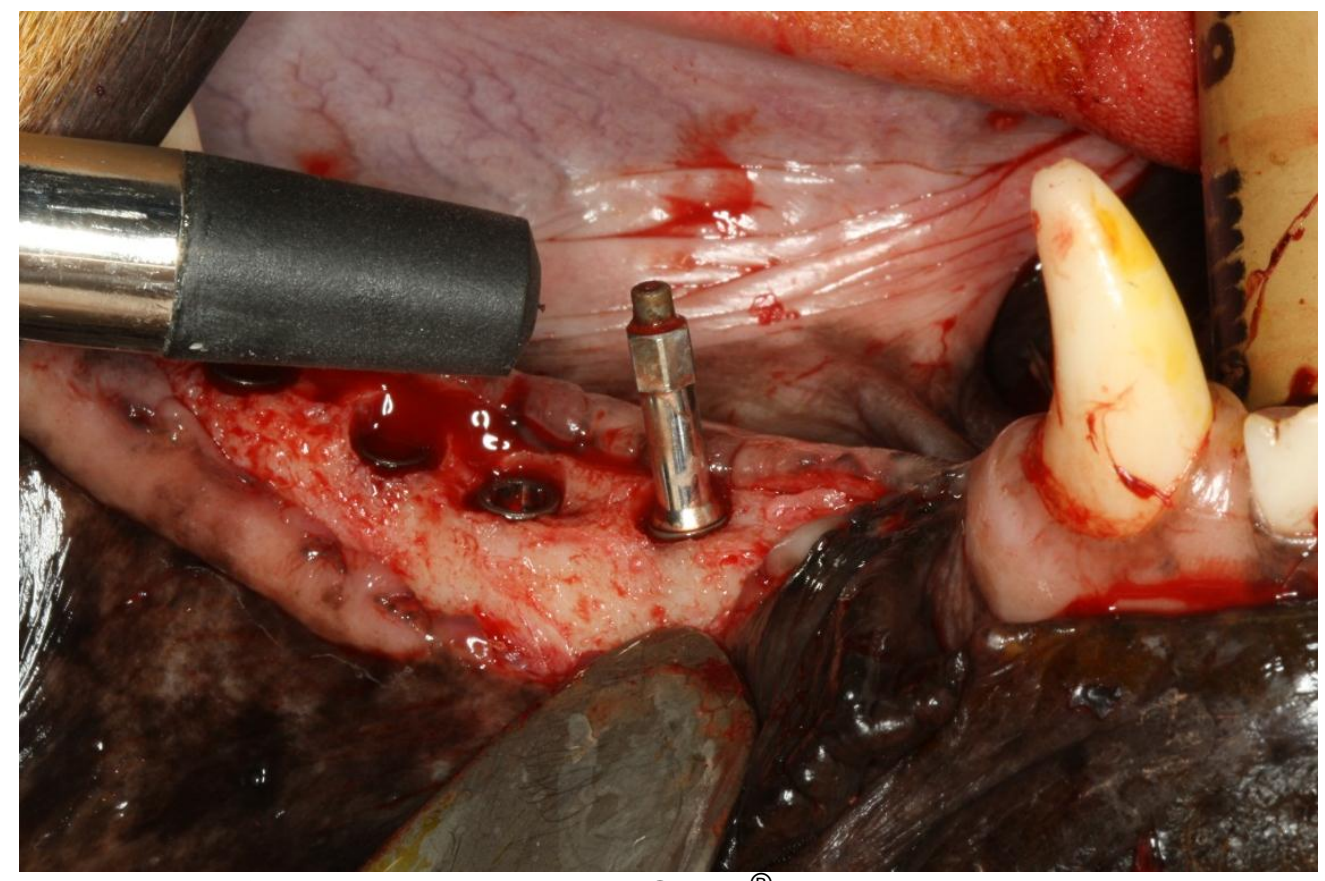

Figura 9 - Aferição do INR com o Ostell ${ }^{\Theta}$ 


\subsection{ANÁLISE DE FLUORESCÊNCIA}

Na primeira semana após a cirurgia de instalação dos implantes no primeiro hemi-arco mandibular, foi administrado por via endovenosa o fluorocromo vermelho de alizarina $(20 \mathrm{mg} / \mathrm{kg}$ - Alizarin Red® - Sigma-Aldrich, St. Louis, Missouri, USA), dissolvido em bicarbonato de sódio $2 \%$, com o objetivo de avaliar a atividade de formação óssea em 3 semanas. A infusão do corante calceína foi realizada na segunda semana após o procedimento de implantação, marcando a atividade de deposição de matriz óssea na terceira e quarta semana de osseointegração.

\subsection{EUTANÁSIA DOS ANIMAIS}

Decorrido o período experimental de dez semanas após a primeira cirurgia de implantação, os animais foram sacrificados por sobredose anestésica de Thiopentax ${ }^{\circledR}$. Após eutanásia, os segmentos das mandíbulas contendo os sítios experimentais e tecidos circunvizinhos foram removidos, dissecados e posteriormente reduzidos em quatro blocos individuais contendo os grupos experimentais a serem estudados.

\subsection{PROCESSAMENTO HISTOLÓGICO E ANÁLISE HISTOMÉTRICA}

Após a remoção, os segmentos ósseos foram fixados em solução de formol 4\% tamponado $(\mathrm{pH}=7)$ por 48 horas e transferidos para uma solução de etanol $70 \%$, onde permaneceram por três dias. Os espécimes foram desidratados em uma série crescente de álcoois e incluídos em resina acrílica LR White ${ }^{\circledR}$ (London Resin Company Ltd., Berkshire, Inglaterra). Os implantes foram seccionados ao 
meio, no sentido mésio-distal, utilizando serra de precisão Microslice $2^{\circledR}$ (Ultra Tec manufacturing Inc., Santa Anna, CA, EUA) e polidos utilizando panos de polimento combinados com $\mathrm{Al}_{2} \mathrm{O}_{3}$ de diferentes granulações. De cada implante foram obtidas duas metades e 3 lâminas histológicas para observação em microscopia de luz. Cada lâmina terá espessura aproximada de $30 \mu \mathrm{m}$ a $40 \mu \mathrm{m}$, que foi desgastada e polida até apresentar aproximadamente $10 \mu \mathrm{m}$ a $20 \mu \mathrm{m}$ de espessura. Cada lâmina será submetida à captura da imagem para análise descritiva e quantitativa de fluorescência, utilizando o sistema de microvídeo (Leica Digital DFC 300FX, Leica Microsystems ${ }^{\circledR}$, Suíça). A análise de fluorescência foi restrita à área do defeito ósseo. As mesmas lâminas foram submetidas à coloração utilizando a combinação de Stevenel's blue com Alizarin Red, conforme descrito por Maniotopoulus et al. (1986), a fim de realizar a análise histológica (microscópio Leica DMLB, Leica Microsystems ${ }^{\circledR}$, Suíça) e medidas histométricas (Leica Qwin, Leica Microsystems ${ }^{\circledR}$, Suíça). As avaliações histométricas e quantitativas de fluorescência foram analisadas, sem o conhecimento prévio dos espécimes experimentais. As medidas morfométricas foram realizadas considerando o contato osso-implante (BIC), a área óssea entre as espiras do implante (BA), a distância entre o ombro do implante e o primeiro contato ósseo com o implante (IS-C) e a área óssea no retângulo (BAR) colocado paralelamente ao implante. Este retângulo foi padronizado com um tamanho que corresponde o defeito ósseo criado $(4,0 \mathrm{~mm}$ de altura e $0,5 \mathrm{~mm}$ de largura).

A análise de fluorescência foi realizada em duas formas para cada marcador utilizado. A primeira, em aumento de 2,5x, criou-se um frame retangular de $4 \mathrm{~mm}$ 
x 0,5 $\mathrm{mm}$ posicionado sobre a região correspondente ao defeito ósseo. Dentro deste frame foi quantificado os marcadores utilizados em cada tempo experimental. Outra análise de fluorescência foi a presença de marcadores entre as espiras, para isso em aumento de 10x marcamos a área correspondente $\mathrm{e}$ quantificamos percentualmente a formação óssea nessa região.

\subsection{MOLHABILIDADE DA SUPERFÍCIE}

Para o teste de hidrofibilidade das superfícies de titânico, foram utilizados 10 discos de titânio com dimensões de $20 \mathrm{~mm}$ de diâmetro por $3 \mathrm{~mm}$ de altura. Os discos foram fabricados e tratados pela empresa Neoss, em 5 discos, foram empregados o mesmo tratamento utilizados para conferir propriedades hidrofílicas e, em 5 discos empregado tratamento para caracterizar a superfície Bimodal.

Com o emprego do goniômetro First Ten Angstrom modelo FTA100 (First Ten Angstroms, Inc., Portsmouth, Virginia, Estados Unidos da América). As medidas dos ângulos de contato foram realizadas com água destilada . Depositou-se $1 \mathrm{ml}$ de gota nas superfícies dos discos e logo em seguida mediuse o ângulo de contato formado entre o liquido e o disco de titânio (Fig 10 e 11). 


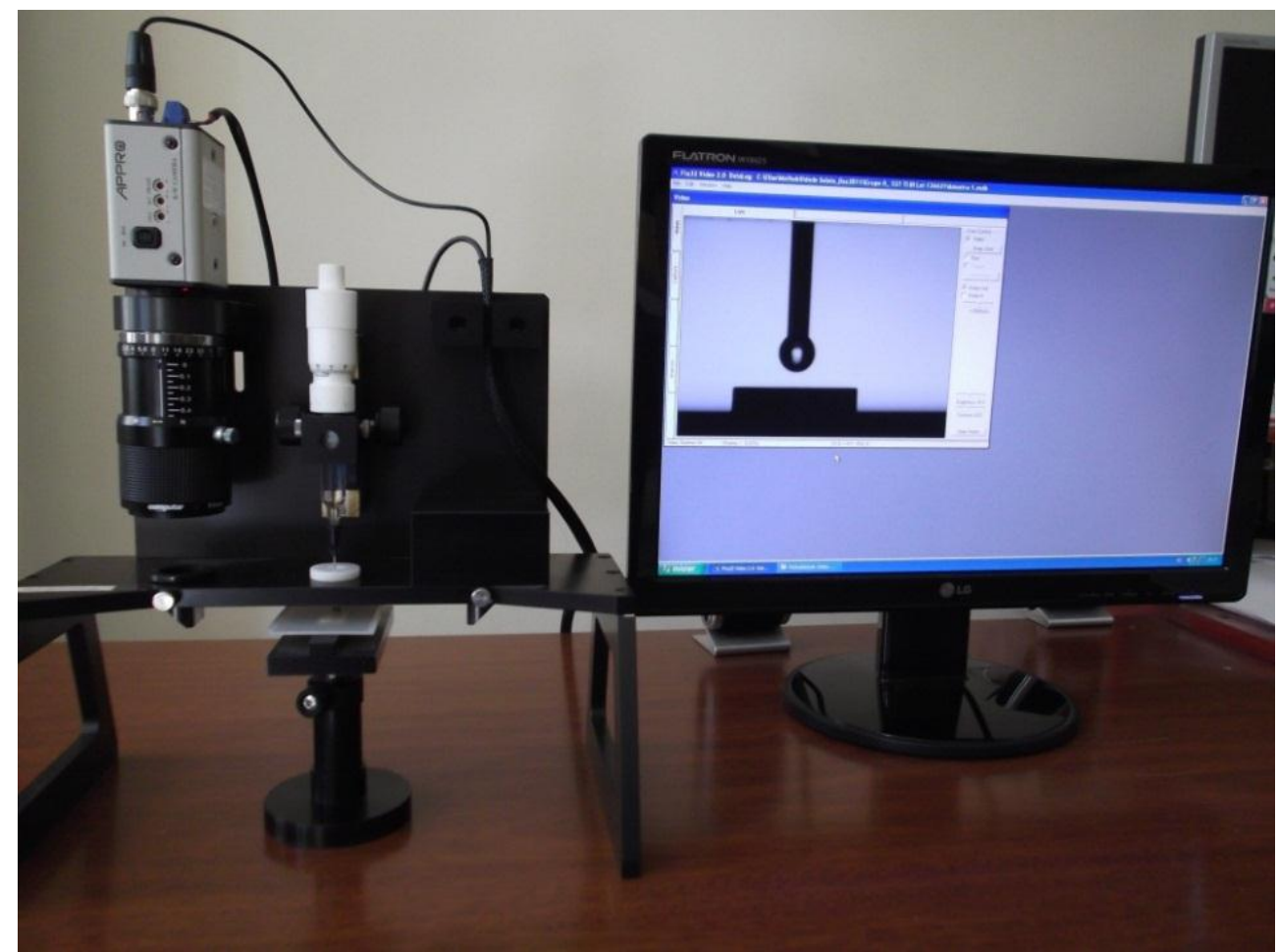

Figura 10 - Goniômetro utilizado para medir ângulo de contato entre o líquido e a superfície do titânio

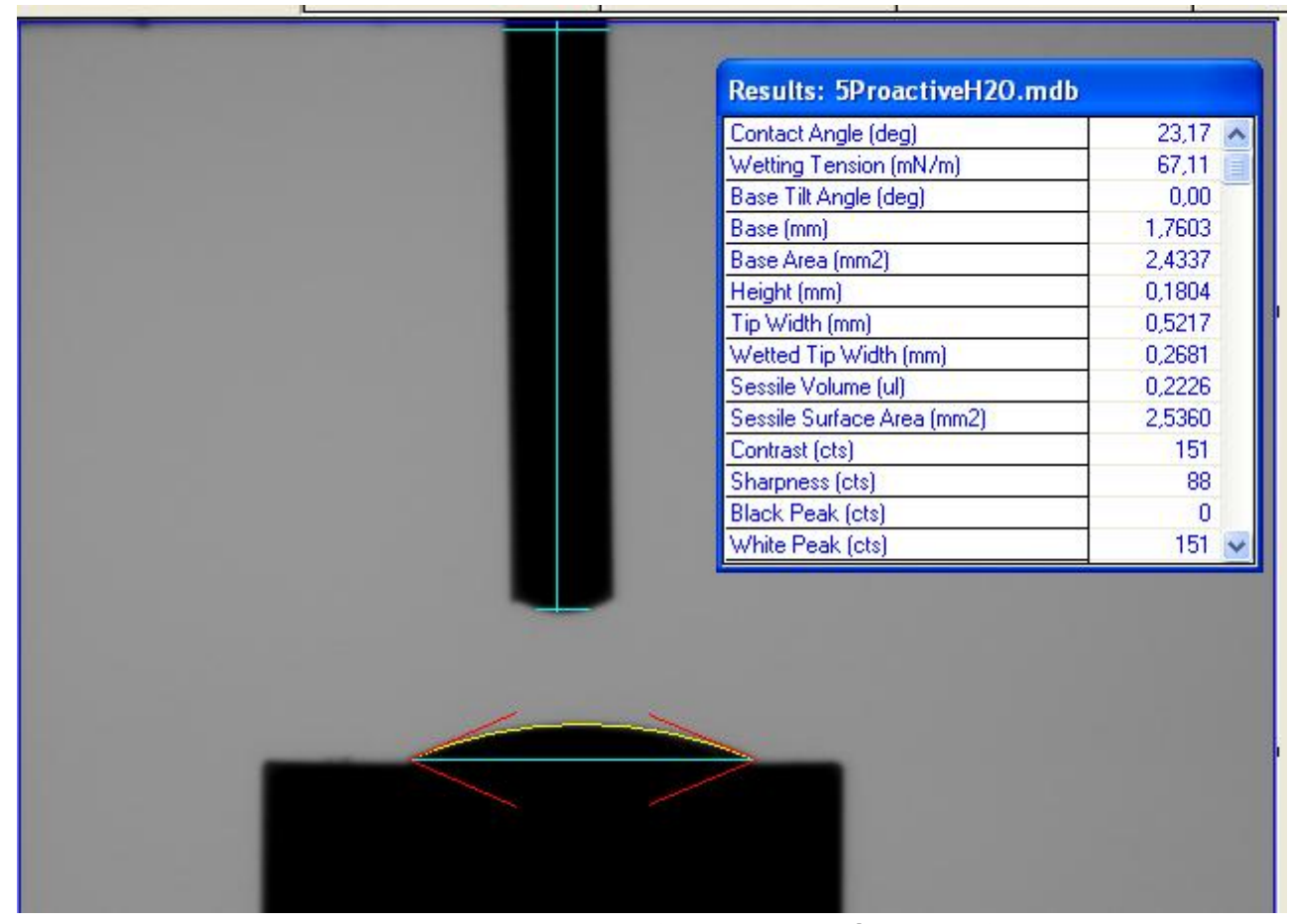

Figura 11: Imagem obtida para aferição do ângulo formado entre a superfície do titânio e o líquido 


\subsection{TOPOGRAFIA}

A análise topográfica foi realizada pelo departamento de engenharia biomédica da Universidade de Rochester, NY. Utilizando interferometro óptico (Zygo 7300, Middlefield, CT-USA). Foi utilizada uma área de varredura de $210 \times$ $280 \mu \mathrm{m}$ (objetiva $50 \times$, zoom 0.5) e filtro gaussiano (tamanho $80 \times 80 \mu \mathrm{m}$ e $2 \times 2 \mu \mathrm{m}$ ) utilizado para remover erros de forma. Três amostras de cada tipo de implante foram analisadas nas regiões coronárias, médias e apicais, perfazendo um total de 27 medidas para cada grupo. Foi tomada atenção especial para que a superfície da rosca permanecesse perpendicular à fonte de luz de forma a se obter imagens com excelentes definições para se estabelecer os parâmetros de rugosidades. A média aritmética da rugosidade superficial em 3D $\left(S_{\mathrm{a}}\right)$, a densidade de picos $\left(S_{\mathrm{ds}}\right)$, e a porcentagem do aumento da superfície $\left(S_{\mathrm{dr}}\right)$. Os parâmetros foram calculados com um programa específico para este fim (Scanning Probe Image Processor, SPIP ${ }^{\text {TM }}$, Image Analysis A/S). 


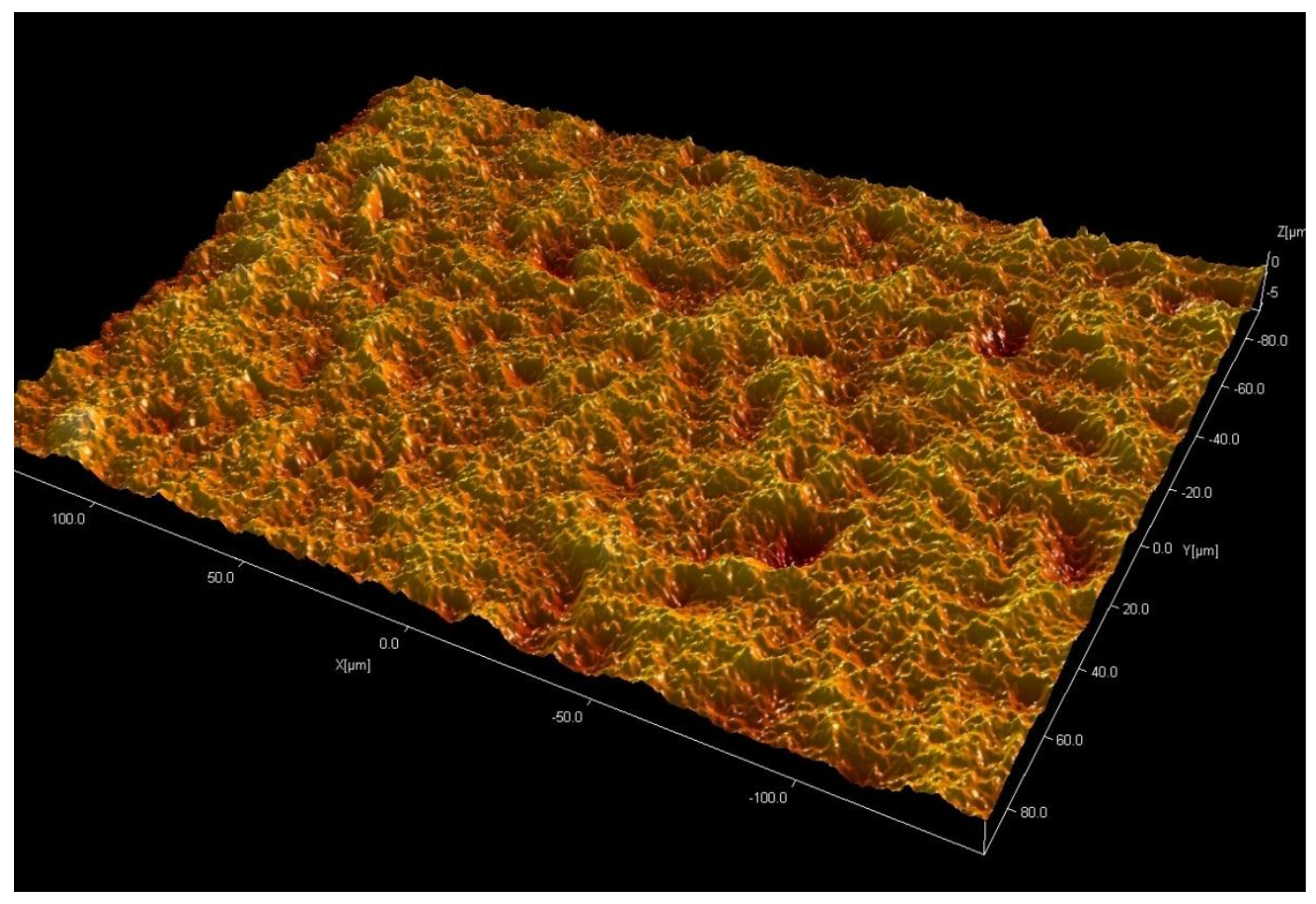

Figura 12 - Interferometria óptica da superfície Bimodal®

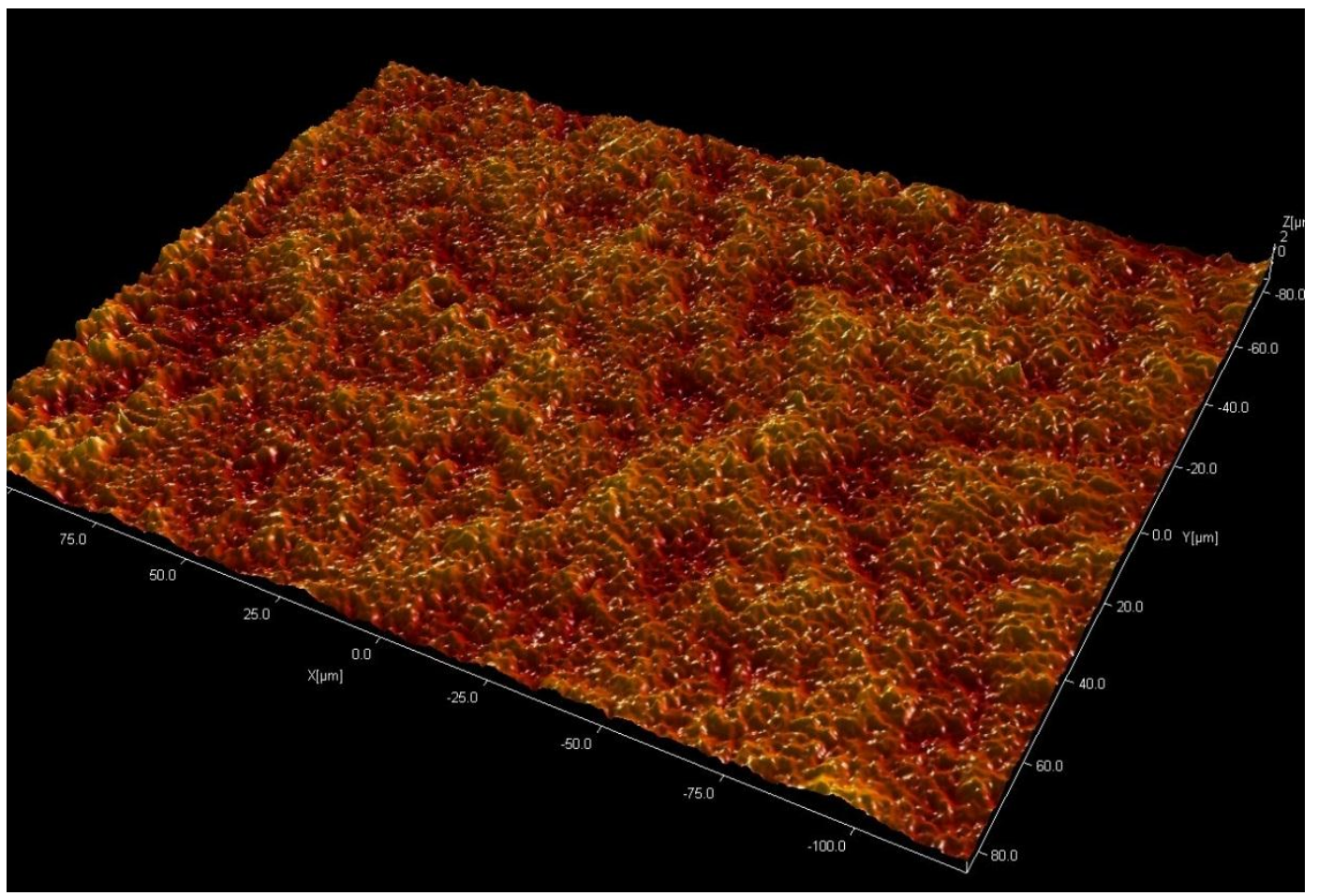

Figura 13 - Interferometria óptica da superfície ProActive® 


\section{RESULTADOS}

Todos os animais suportaram bem os procedimentos cirúrgicos. As 3 intervenções foram realizadas sem intercorrências, não houve perda de implantes e nenhum cão apresentou complicações no período pós-operatório que pudessem comprometer as análises.

\section{Análise de frequência de ressonância (RFA)}

As medidas da frequência de ressonância obtidas no momento da instalação dos implantes e no momento da eutanásia mostraram aumento da estabilidade em todos os grupos. Não houve diferença entre estabilidade inicial ou ganho de estabilidade no que diz respeito à superfície de implante utilizada, porém os implantes de ambas as superfícies que aguardaram 4 semanas de osseointegração obtiveram valores maiores no momento da eutanásia, em relação aos implantes que aguardaram apenas 1 semana (Tabela1 e Gráfico 1).

Tabela 1 - Comparação da estabilidade entre tipos de superfícies de implantes e entre tempos utilizando RFA.

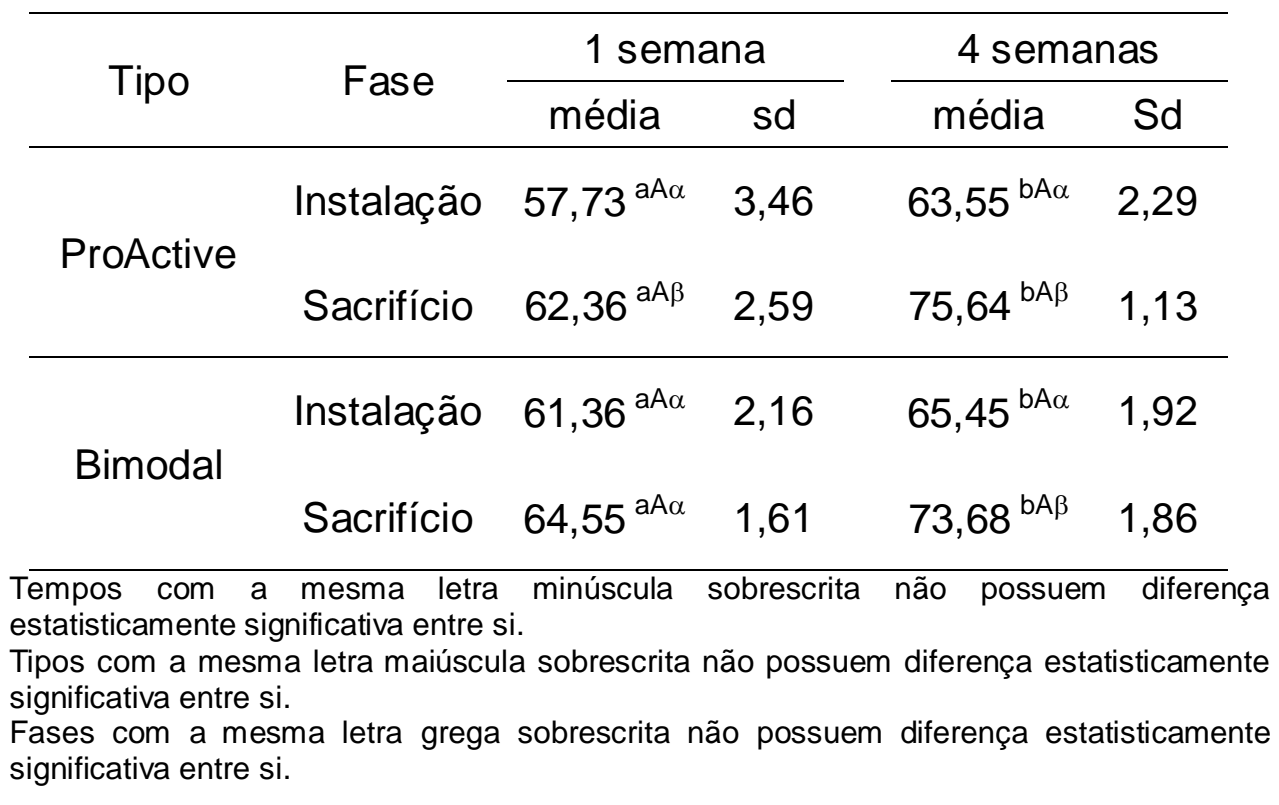




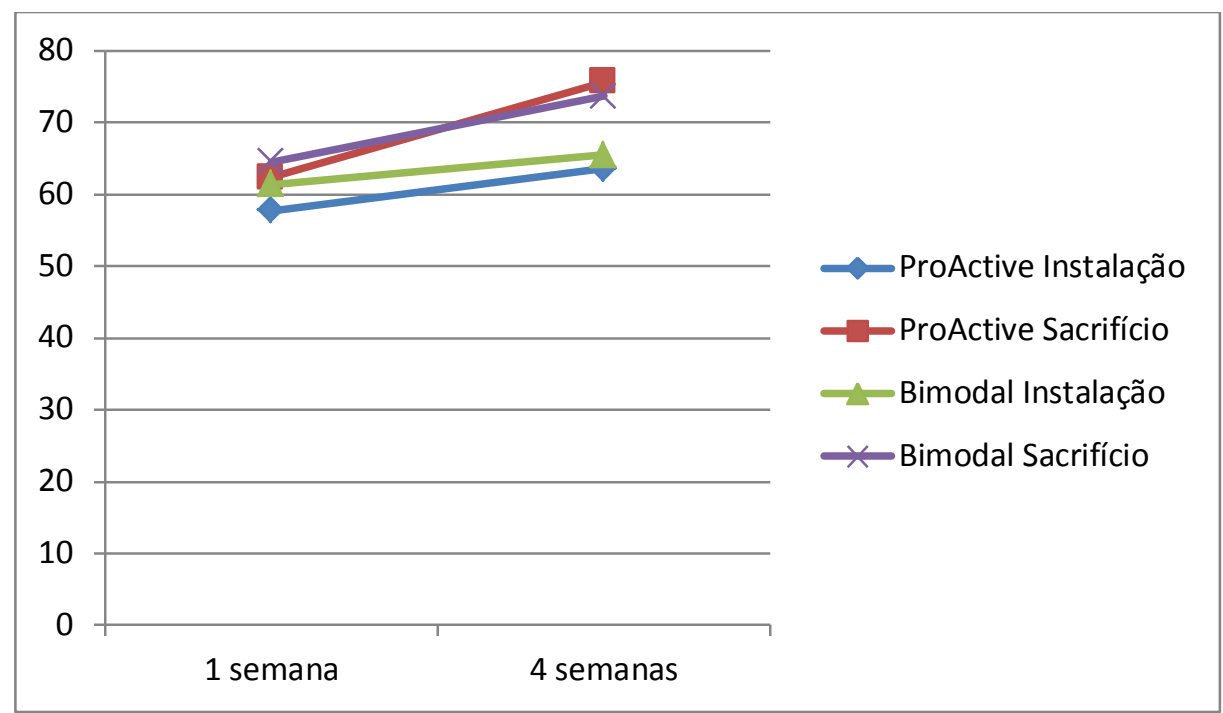

Gráfico 1 - Comparação da estabilidade entre superfícies de implantes e entre tempos utilizando RFA.

\section{ANÁLISE HISTOLÓGICA}

A análise histológica mostrou que o tratamento de superfície não alterou a formação óssea ao redor do implante em nenhum dos momentos estudados. Após uma semana da instalação dos implantes observou-se a presença de tecido de granulação no defeito ósseo nas duas superfícies estudadas. Após 4 semanas, existia a presença de osso neoformado na periferia do defeito, indicando osteogênese à distância e pouca formação óssea em contato com o implante (Figura 14) 


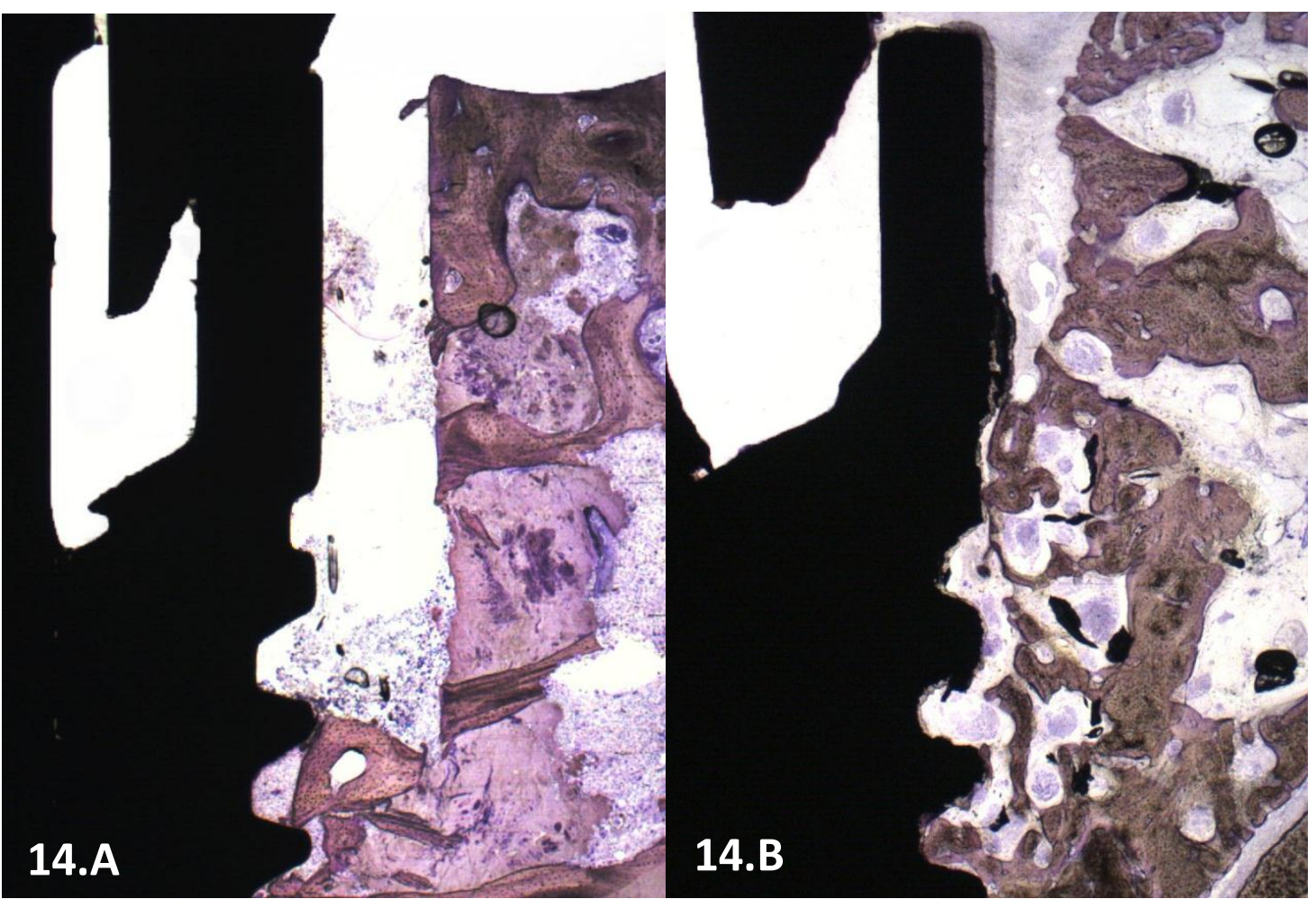

Figura 14 - Aspecto histológico da região do defeito ósseo nos tempos de 1 semana (A) e 4 semanas de osseointegração (B). Observa-se presença de tecido de granulação com infiltrado inflamatório no defeito ósseo após uma semana de reparo ósseo e presença de osso neoformado preenchendo o defeito após 4 semanas de reparo. (Aumento de 2,5x)

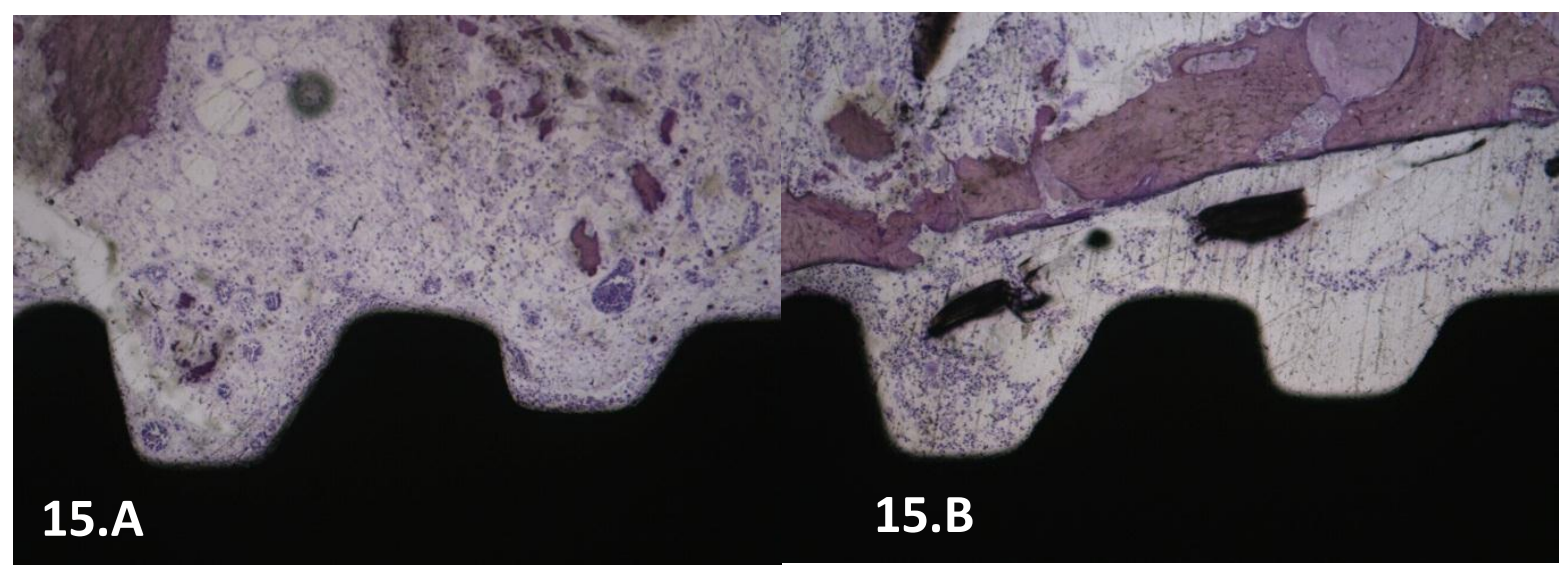

Figura 15 - Aspecto histológico dos implantes Bimodal (A) e ProActive (B) após uma semana de instalação (Aumento de 10x). 


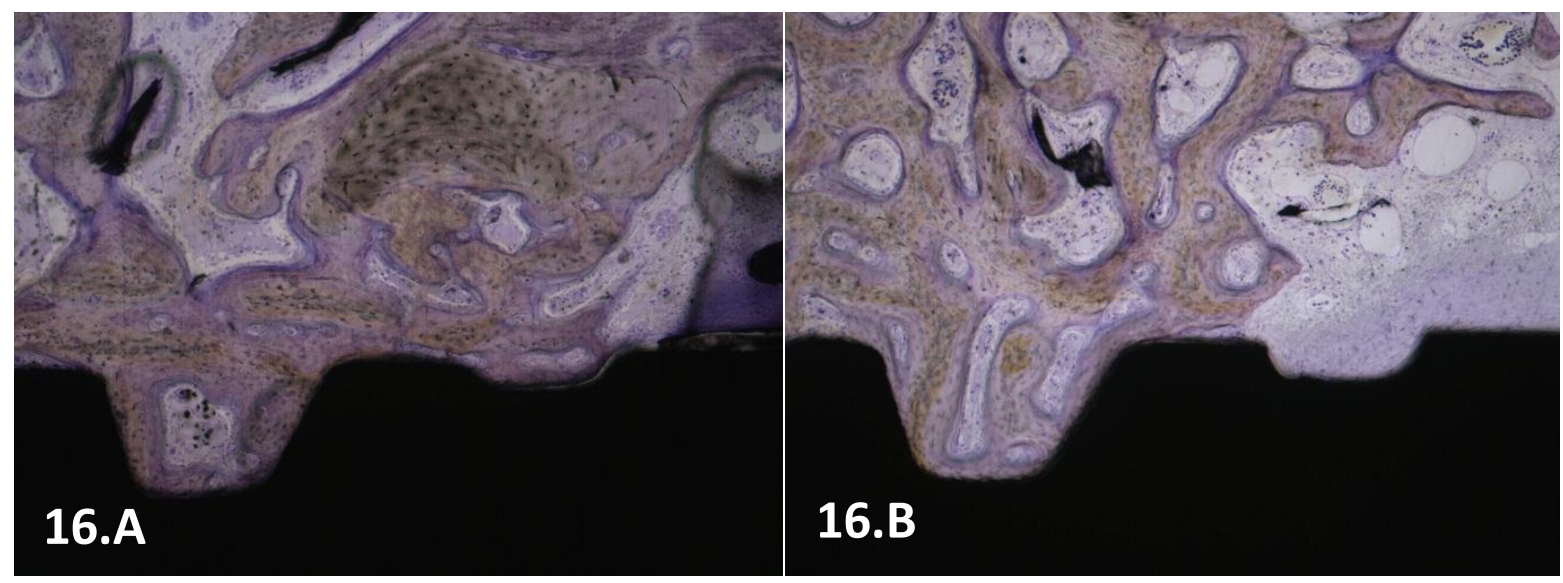

Figura 16 - Aspecto histológico dos implantes Bimodal (A) e ProActive (B) após 4 semanas de instalação (Aumento de 10x).

\section{ANÁLISE HISTOMORFOMÉTRICA}

\section{Área de osso formado entre as espiras (BA)}

$\mathrm{Na}$ análise histométrica do osso presente na área formada entre as espiras do implante, a região do terço médio e apical, fora do defeito e em contato íntimo com o implante, apresentou valores maiores que as espiras localizadas dentro do defeito ósseo, não houve diferença estatística entre a superfície hidrofílica e a Bimodal na comparação entre ambas as situações nos dois tempos. Após 4 semanas de instalação, observa-se o aumento da quantidade de tecido ósseo presente em todos os grupos, sem haver diferença entre superfícies (Tabela 2 e Gráfico 2). 
Tabela 2 - Comparações entre grupos da presença de tecido ósseo entre roscas (BA) no defeito ósseo e na região apical (osso nativo), para cada tempo experimental (Aumento de 10x).

\begin{tabular}{|c|c|c|c|c|c|}
\hline \multirow{2}{*}{ Local } & \multirow{2}{*}{ Tipo } & \multicolumn{2}{|c|}{1 semana } & \multicolumn{2}{|c|}{4 semanas } \\
\hline & & Média & Sd & média & Sd \\
\hline \multirow{2}{*}{ Apical * } & ProActive & $33,10^{a A \alpha}$ & 5,80 & $54,87^{\mathrm{bA \alpha}}$ & 5,26 \\
\hline & Bimodal & $46,16^{\mathrm{aA \alpha}}$ & 6,29 & $55,91^{\mathrm{bA} \alpha}$ & 6,78 \\
\hline \multirow{2}{*}{$\begin{array}{l}\text { Defeito } \\
\text { ósseo * }\end{array}$} & ProActive & $21,21^{\mathrm{aA} \beta}$ & 5,74 & $33,81^{\mathrm{bA} \beta}$ & 8,67 \\
\hline & Bimodal & $23,47^{\mathrm{aA} \beta}$ & 5,86 & $43,15^{\mathrm{bA} \beta}$ & 10,34 \\
\hline $\begin{array}{l}\text { pos com } \\
\text { tisticamente } \\
\text { s com a me } \\
\text { ificativa entr } \\
\text { ais com a r }\end{array}$ & $\begin{array}{l}\text { mesma letr } \\
\text { ificativa entre } \\
\text { letra maiúsc } \\
\text { na letra gres }\end{array}$ & $\begin{array}{l}\text { minúscula } \\
\text { a sobrescrita }\end{array}$ & obres & não poss & \\
\hline
\end{tabular}

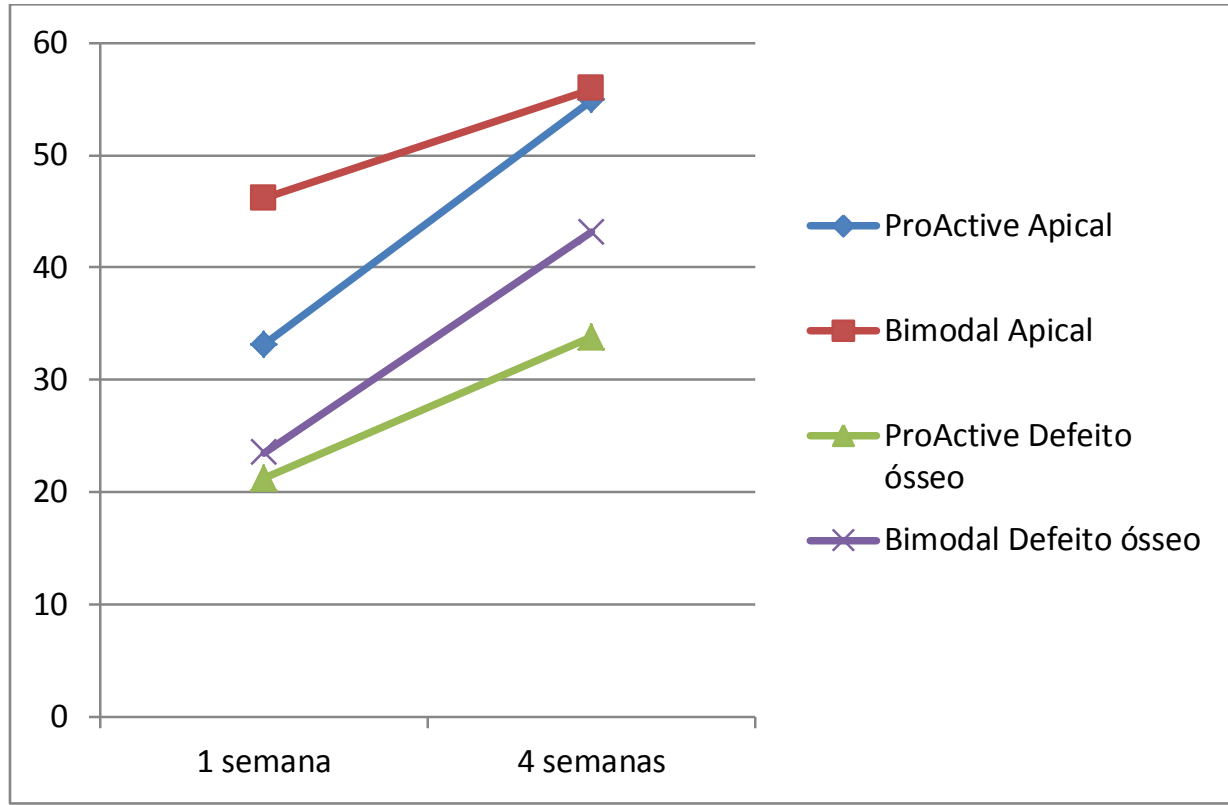

Gráfico 2 - Comparações entre grupos da presença de tecido ósseo entre roscas (BA) no defeito ósseo e na região apical (osso nativo), para cada tempo experimental 


\section{Contato entre osso e implante (BIC)}

A porcentagem de osso em contato com a superfície do implante nas espiras presentes dentro do defeito ósseo foi substancialmente menor que nas espiras instaladas em osso nativo. Ambas as superfícies demonstraram aumento de contato semelhante entre osso e implante ao longo da osseointegração, sem haver diferença estatística entre elas (Tabela 3 e Gráfico 3).

Tabela 3 - Comparações entre grupos da presença de contato ossoimplante (BIC) no defeito ósseo e na região apical (osso nativo), para cada tempo experimental (Aumento de 10x).

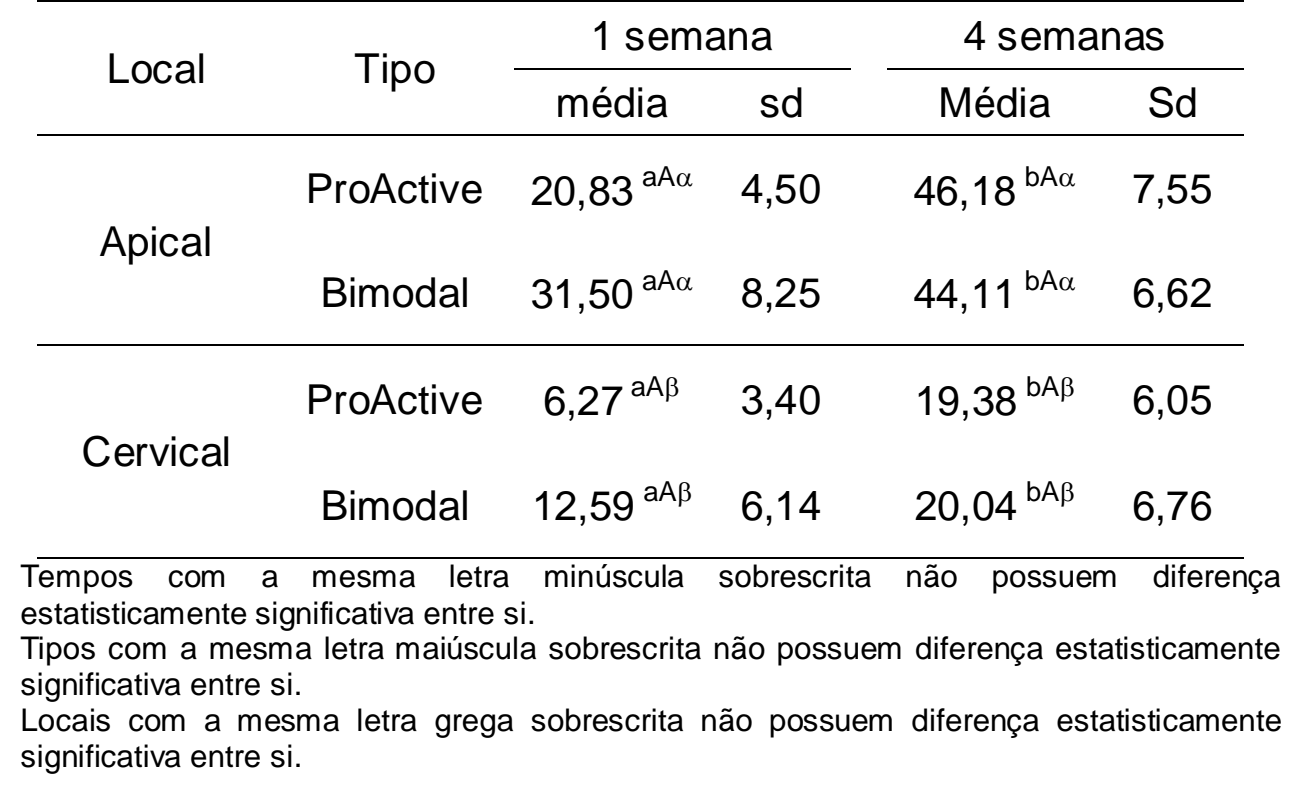




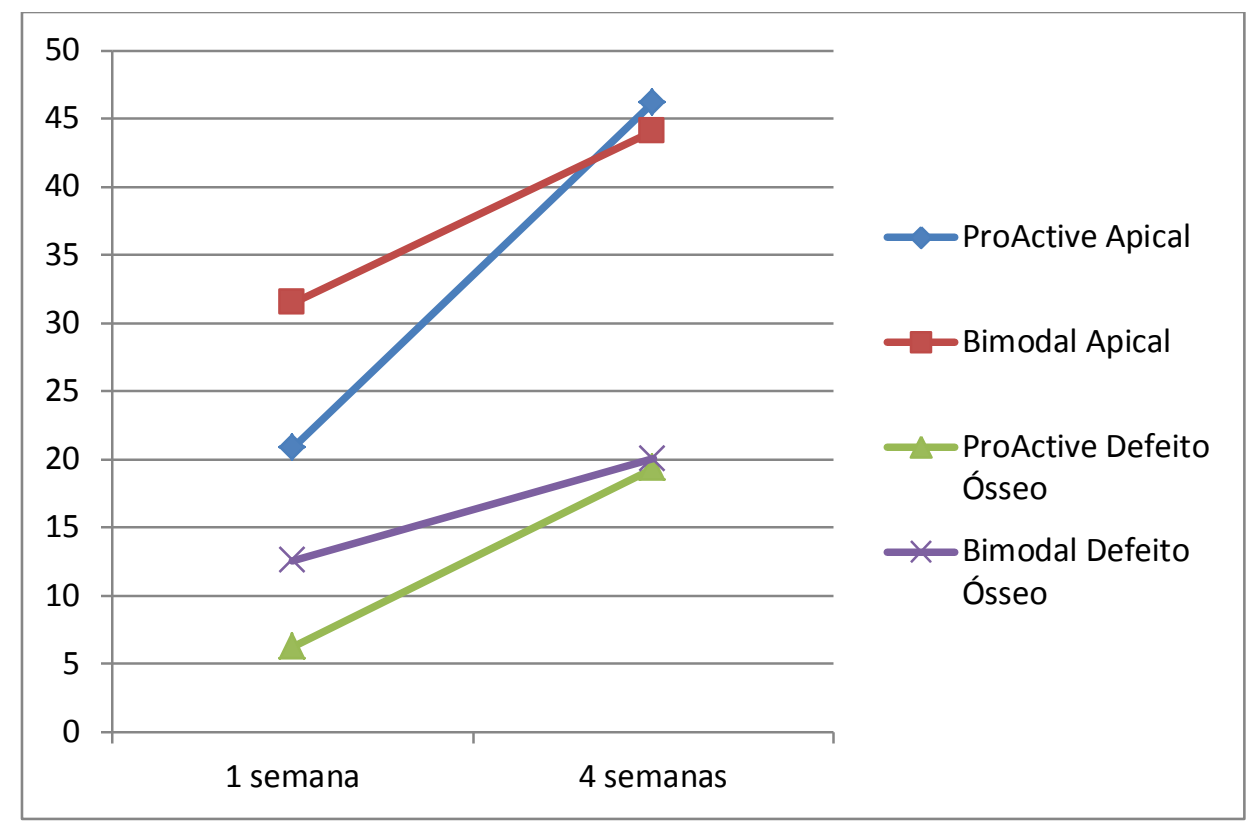

Gráfico 3 - Comparações entre grupos da presença de contato osso-implante (BIC) no defeito ósseo e na região apical (osso nativo), para cada tempo experimental.

\section{Formação óssea na região do defeito ósseo (ROI)}

A comparação entre superfícies quanto à quantidade óssea em percentual de osso formado na região do defeito ósseo é apresentada na tabela 4. Ambas as superfícies demonstraram um aumento da quantidade percentual óssea formada, no período de 4 semanas em relação à 1 semana de osseointegração. Porém não existiu diferença estatística entre elas em nenhum dos dois tempos estudados (Figura 17, Tabela 4 e Gráfico 4). 


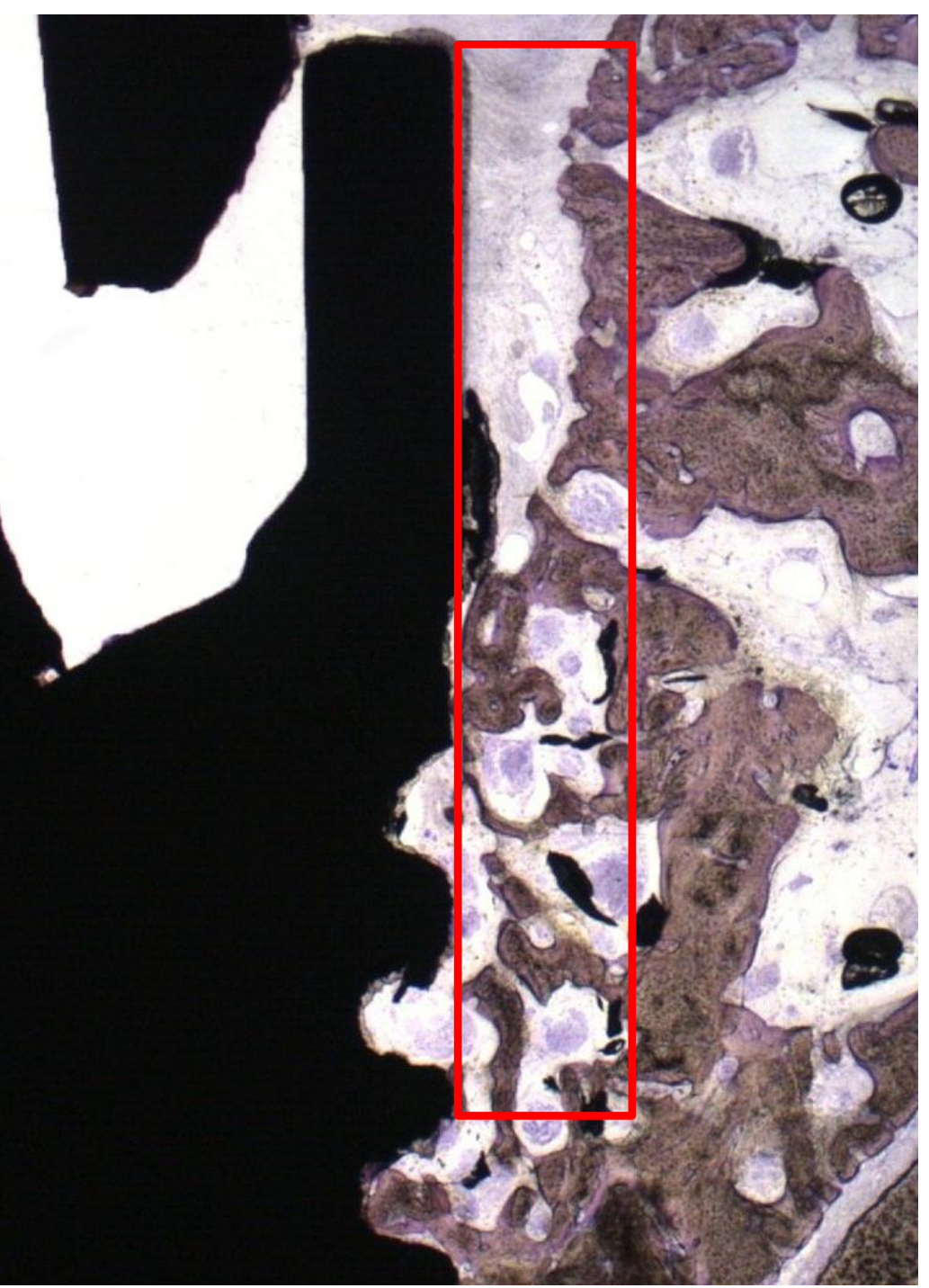

Figura 17 : Obtenção da formação óssea na região do defeito (ROI) (Aumento de 2,5X)

Tabela 4 - Comparações entre grupos da presença de tecido ósseo na região do defeiro ósseo (ROI), para cada tempo experimental

\begin{tabular}{ccccccc}
\hline \multirow{2}{*}{ Tipo } & \multicolumn{2}{c}{1 semana } & & \multicolumn{2}{c}{4 semanas } \\
\cline { 2 - 3 } \cline { 5 - 6 } & média & sd & & média & Sd \\
\hline ProActive & $0,46^{\mathrm{aA}}$ & 0,04 & & $0,76^{\mathrm{bA}}$ & 0,06 \\
Bimodal & $0,56^{\mathrm{aA}}$ & 0,08 & & $0,80^{\mathrm{bA}}$ & 0,09
\end{tabular}

Tempos com a mesma letra minúscula sobrescrita não possuem diferença estatisticamente significativa entre si.

Tipos com a mesma letra maiúscula sobrescrita não possuem diferença estatisticamente significativa entre si. 


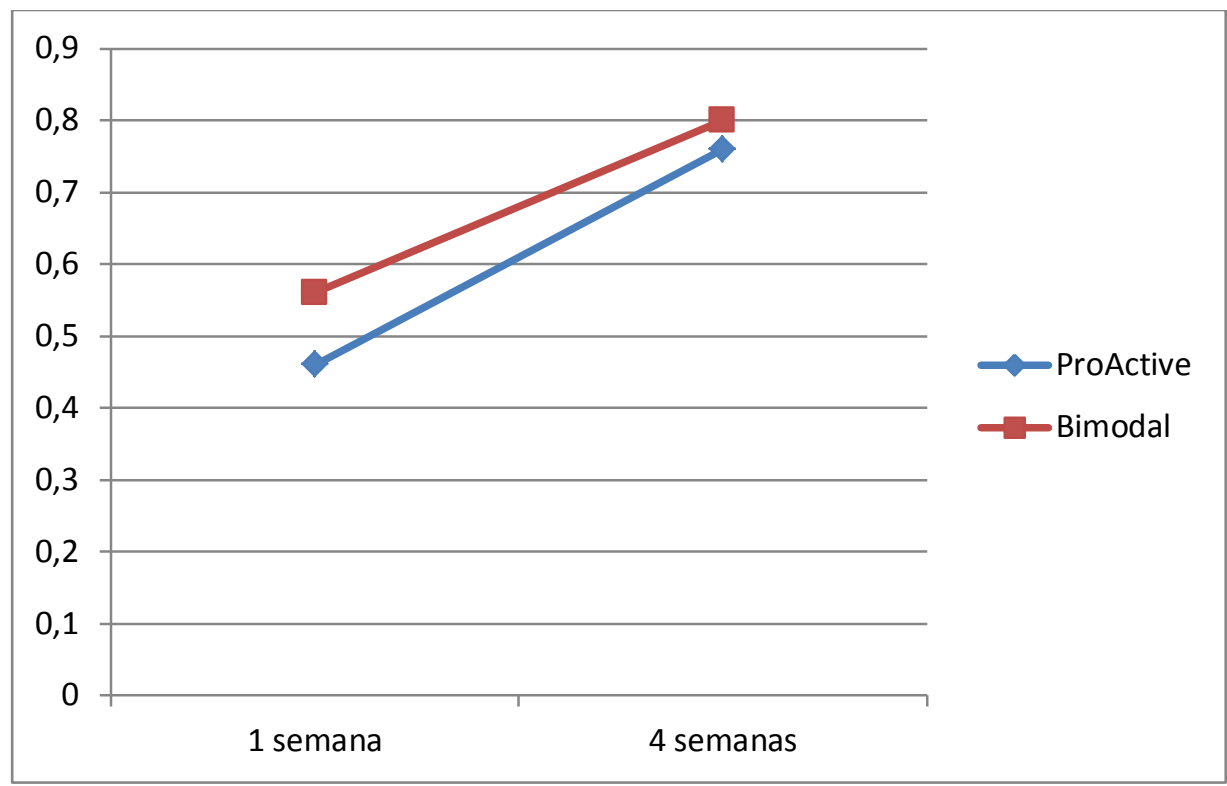

Gráfico 4 - Comparações entre grupos da presença de tecido ósseo na região do defeiro ósseo (ROI), para cada tempo experimental.

\section{Distância entre o ombro do implante e contato ósseo (IS-C)}

$\mathrm{Na}$ análise da menor distância entre o ombro do implante e o ponto de contato mais coronal entre osso e implante, ambas as superfícies no período de uma semana de osseointegração apresentaram valores semelhantes, próximas à profundidade do defeito ósseo realizado previamente à instalação do implante. Após quatro semanas de osseointegração os valores diminuíram de maneira similar (Figura 18, Tabela 5 e Gráfico 5). 


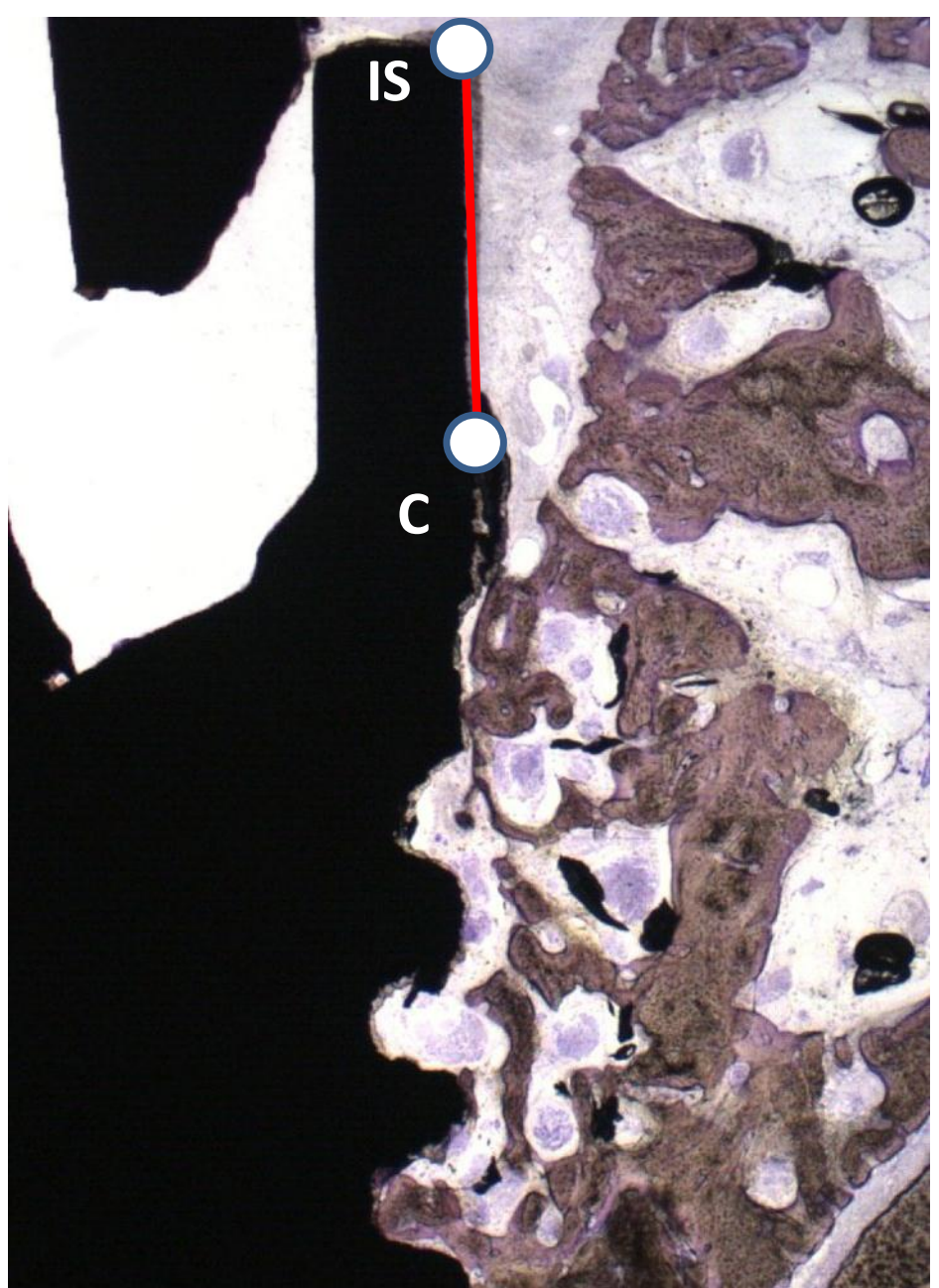

Figura 18: Aferição entre a distância do ombro do implante ao primeiro contato ósseo (IS-C) (Aumento 10X).

Tabela 5 - Comparação entre tipos de superfície de implante em relação ao IS-C

\begin{tabular}{ccclll}
\hline \multirow{2}{*}{ Tipo } & \multicolumn{2}{c}{1 semana } & & \multicolumn{2}{c}{4 semanas } \\
\cline { 2 - 3 } \cline { 5 - 6 } & média & Sd & & média & Sd \\
\hline ProActive & $3,45^{\text {aA }}$ & 0,25 & & $2,62^{\mathrm{bA}}$ & 0,21 \\
Bimodal & $3,18^{\mathrm{aA}}$ & 0,38 & & $2,37^{\mathrm{bA}}$ & 0,27
\end{tabular}

Tempos com a mesma letra minúscula sobrescrita não possuem diferença estatisticamente significativa entre si.

Tipos com a mesma letra maiúscula sobrescrita não possuem diferença estatisticamente significativa entre si. 


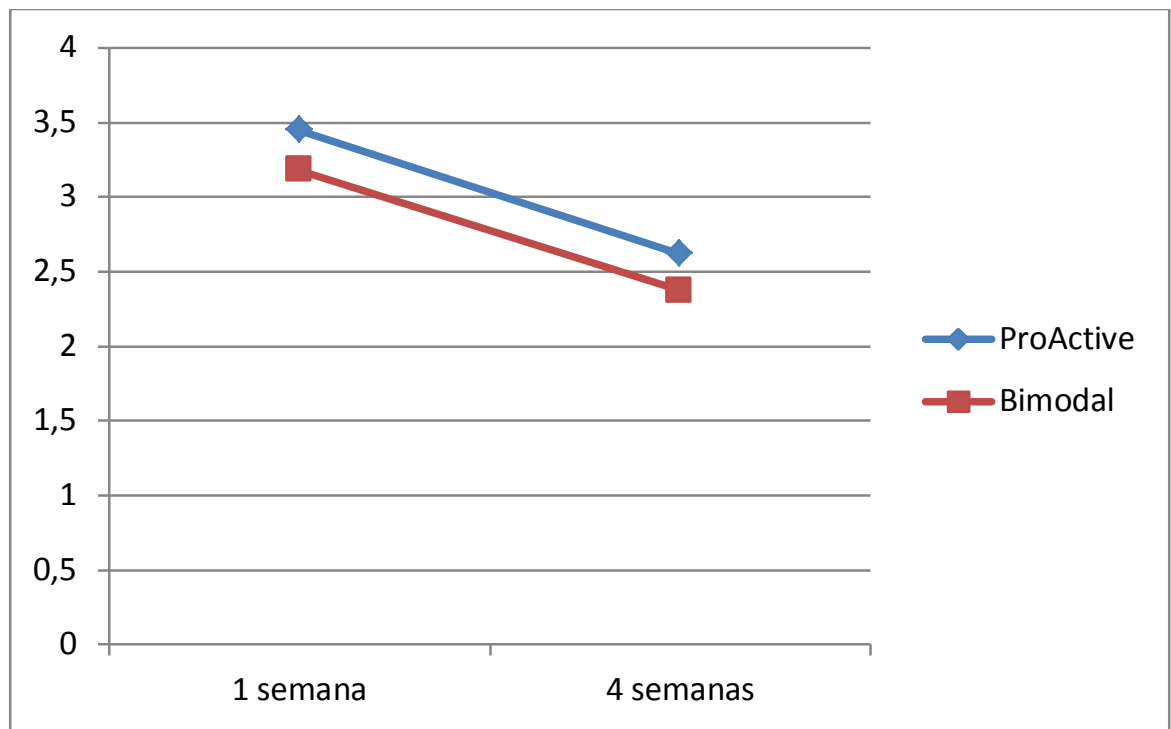

Gráfico 5 - Comparação entre tipos de superfície de implante em relação ao IS-C.

\section{Fluorescência}

Avaliando os marcadores da fluorescência, foi possível verificar o aumento da formação de matriz óssea ao longo do período de acompanhamento, fato que pode ser constatado pelo aumento da quantidade marcadores de uma semana em relação a quatro semanas. Apesar deste comportamento já ser esperado, não foi constatado diferença entre as superfícies quando confronta-se os dois grupos em cada tempo estudado. $\mathrm{Na}$ análise da quantidade de osso formado na região correspondente ao defeito ósseo (ROI) comportamento foi semelhante, com aumento significativo da quantidade de matriz óssea após 4 semanas de osseointegração, em relação à 1 semana de osseointegração (Tabelas 6 e 7; Gráficos 6 e 7; Figuras 19 e 20). 
Tabela 6 - Formação óssea entre ROls comparando dados de fluorescência utilizando alizarina e calceína, para cada tempo experimental (Aumento de 2.5x).

\begin{tabular}{cccccccc}
\hline \multirow{2}{*}{ Aumento } & \multirow{2}{*}{ Tipo } & \multicolumn{2}{c}{1 semana } & & \multicolumn{2}{c}{4 semanas } \\
\cline { 3 - 4 } \cline { 7 - 8 } Alizarina & ProActive & $0,06^{\mathrm{aA}}$ & 0,04 & & $0,28^{\mathrm{bA}}$ & 0,08 \\
& Controle & $0,11^{\mathrm{aA}}$ & 0,06 & & $0,27^{\mathrm{bA}}$ & 0,06 \\
\hline \multirow{2}{*}{ Calceína } & ProActive & $0,12^{\mathrm{aA}}$ & 0,04 & & $0,83^{\mathrm{bA}}$ & 0,14 \\
& Controle & $0,42^{\mathrm{aA}}$ & 0,21 & & $0,91^{\mathrm{bA}}$ & 0,14
\end{tabular}

Tempos com a mesma letra minúscula sobrescrita não possuem diferença estatisticamente significativa entre si.

Tipos com a mesma letra maiúscula sobrescrita não possuem diferença estatisticamente significativa entre si.

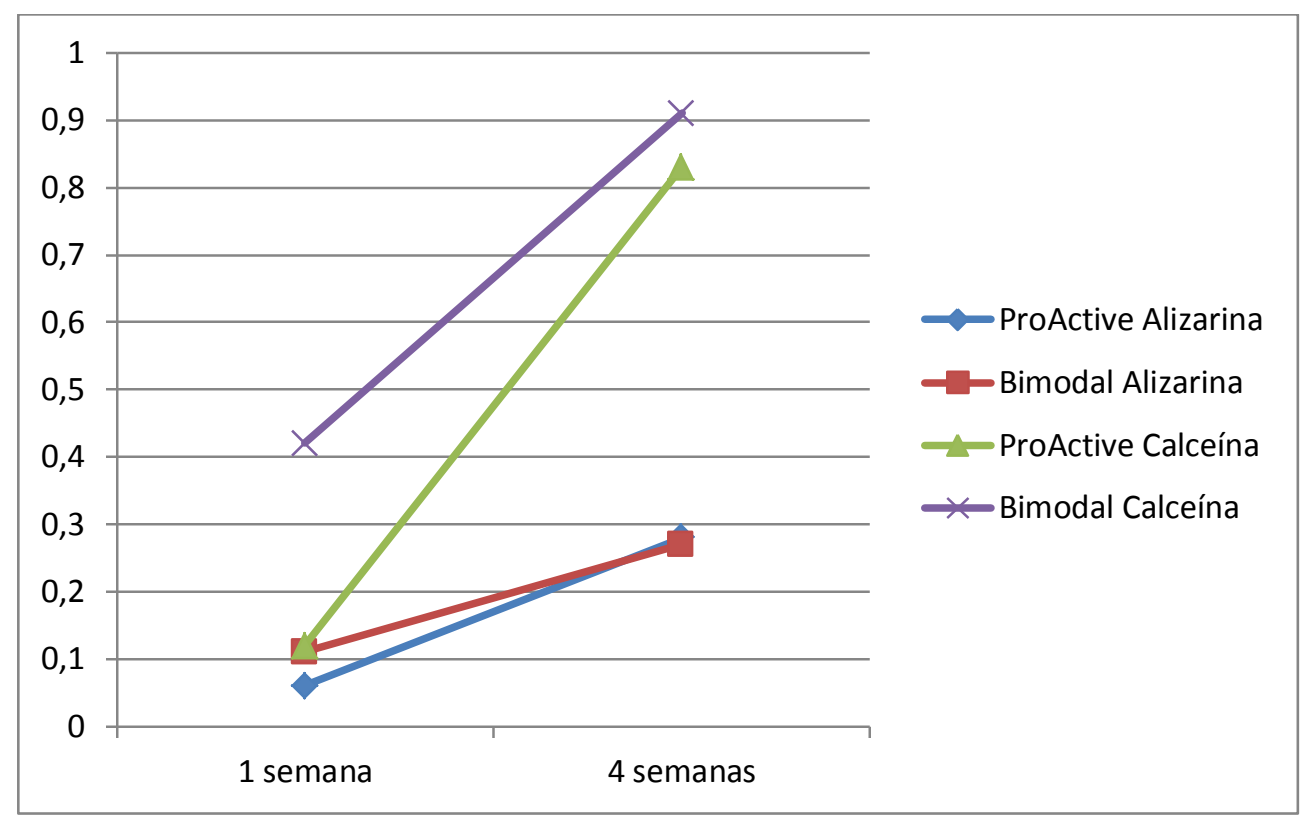

Gráfico 6 - Formação óssea entre ROls comparando dados de fluorescência utilizando alizarina e calceína, para cada tempo experimental. 

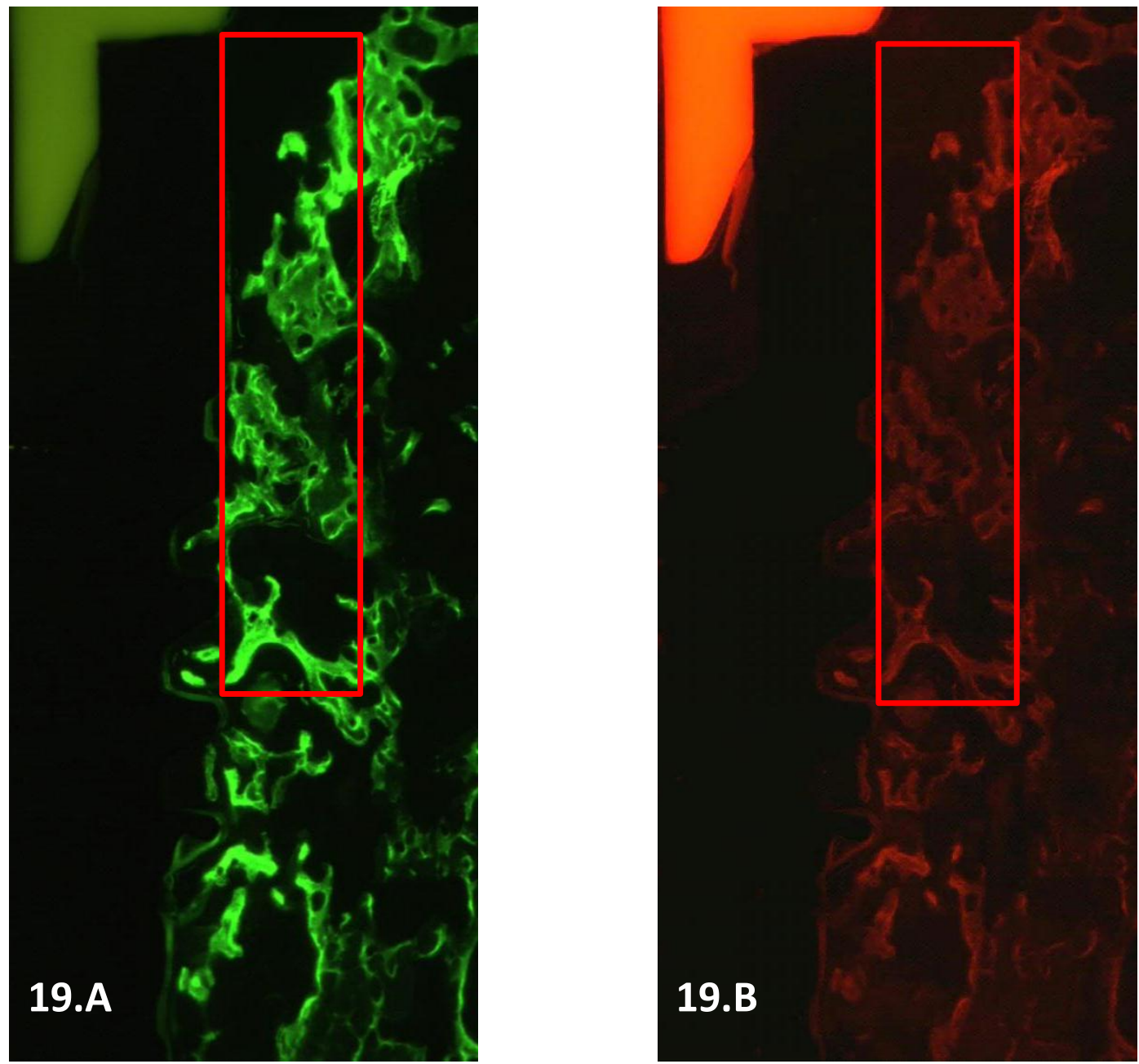

Figura 19: Análise da fluorescência na região do defeito cervical (ROI). Figura A mostrando a evidenciação da calceína e a figura B a evidenciação da alizarina (Aumento de 2,5x)

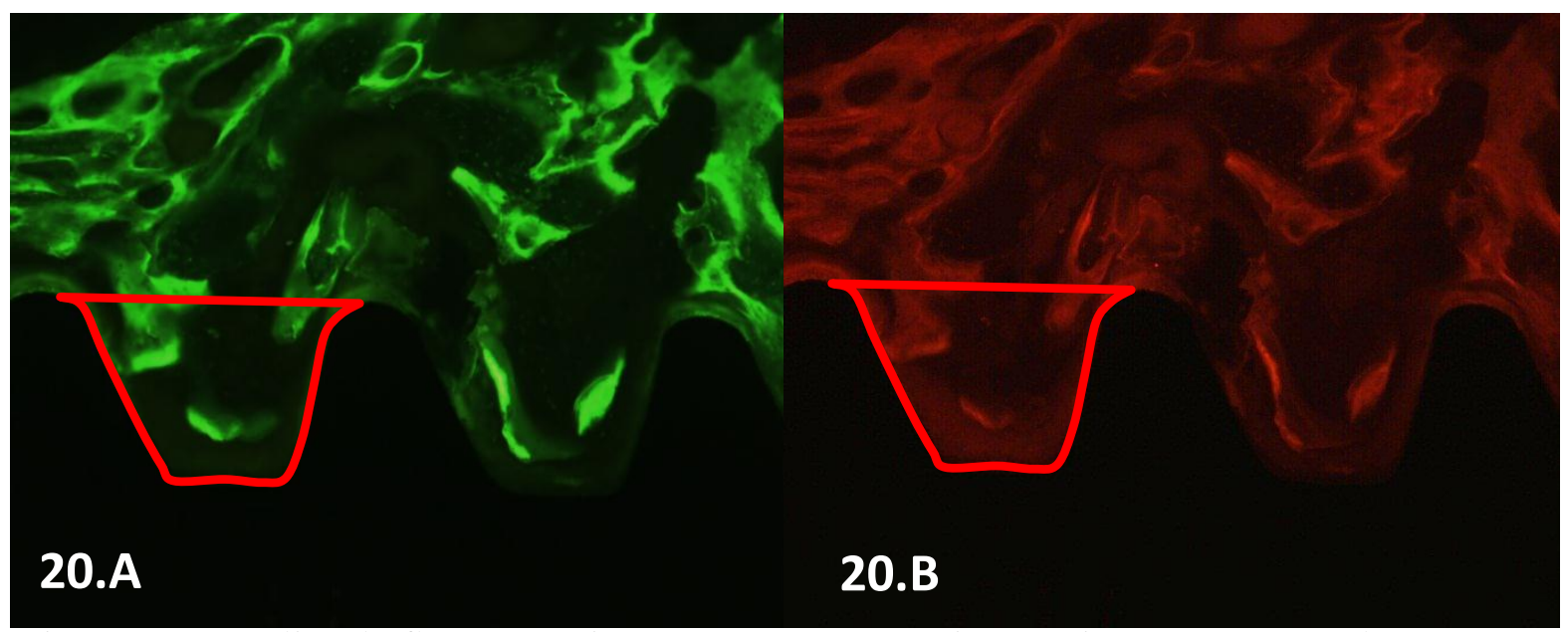

Figura 20 : Análise da fluorescência na área entre as espiras. ).Figura A mostrando a evidenciação da calceína e a figura $\mathrm{B}$ a evidenciação da alizarina (Aumento de 10x) 
Tabela 7 - Formação óssea entre BAs comparando dados de fluorescência utilizando alizarina e calceína, para cada tempo experimental (Aumento de 10x).

\begin{tabular}{ccccccc}
\multirow{2}{*}{ Aumento } & \multirow{2}{*}{ Tipo } & \multicolumn{2}{c}{1 semana } & & \multicolumn{2}{c}{4 semanas } \\
\cline { 3 - 4 } \cline { 6 - 7 } & ProActive & $0,54^{\mathrm{aA}}$ & 0,41 & & $2,63^{\mathrm{bA}}$ & 0,68
\end{tabular}

Alizarina

\begin{tabular}{lllll} 
Bimodal & $0,82^{\mathrm{aA}}$ & 0,50 & $1,67^{\mathrm{bA}}$ & 0,23 \\
\hline ProActive & $0,40^{\mathrm{aA}}$ & 0,28 & $2,84^{\mathrm{bA}}$ & 0,56
\end{tabular}

Calceína

Bimodal $\quad 1,66^{\mathrm{aA}} \quad 0,88 \quad 3,18^{\mathrm{bA}} \quad 0,64$

Tempos com a mesma letra minúscula sobrescrita não possuem diferença estatisticamente significativa entre si.

Tipos com a mesma letra maiúscula sobrescrita não possuem diferença estatisticamente significativa entre si.

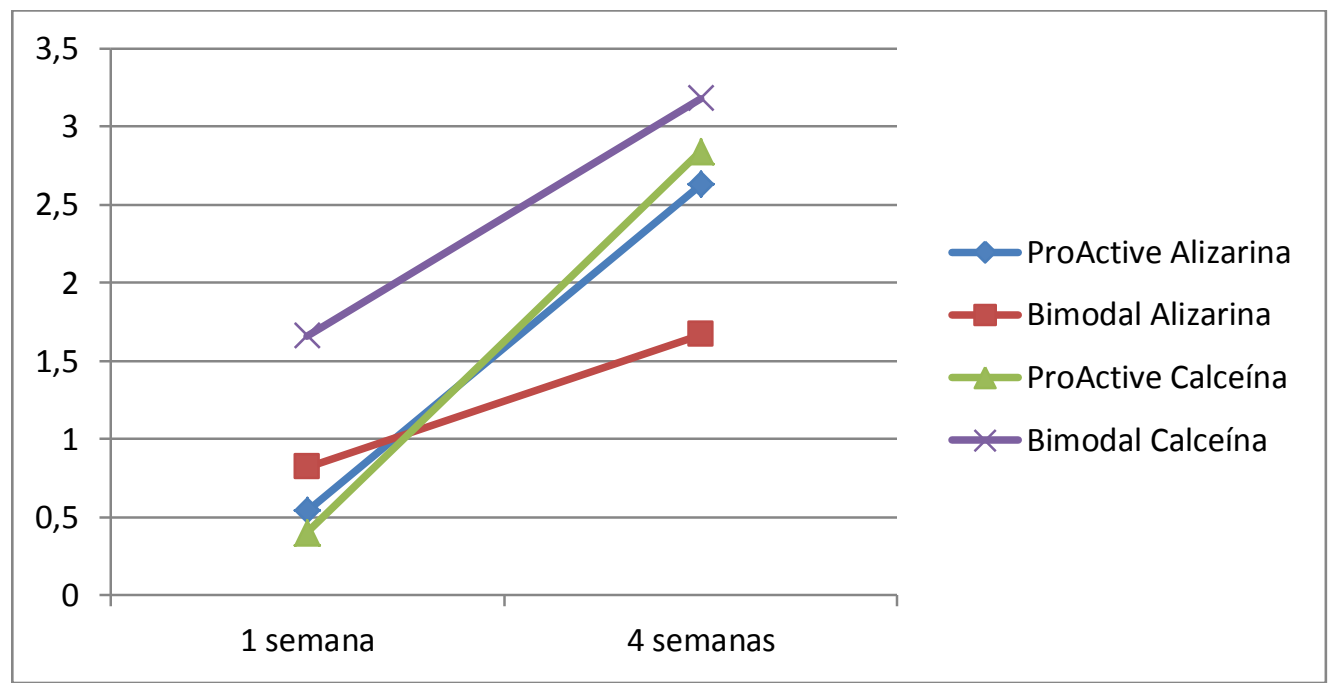

Gráfico 7 - Formação óssea entre BAs comparando dados de fluorescência utilizando alizarina e calceína, para cada tempo experimental.

\section{Molhabilidade das superfícies}

O ângulo de contato entre o líquido e o titânio foi de maneira geral, menor nos discos que foram submetidos ao tratamento da superfície ProActive, demonstrando um comportamento referente à maior energia de superfície e maior umectabilidade. O mesmo teste realizado na superfície controle apresentou formação de maiores ângulos entre a água destilada e o titânio, comprovada pelo 
teste $t$ pareado com diferenças estatisticamente significantes $(p=0.001)$. A superfície Bimodal, expressa, dessa maneira, menor energia de superfície em relação à superfície ProActive, como podemos observar na tabela 8.

Tabela 8 - Comparação entre os ângulos de contato entre as superfícies analisadas nos testes com água destilada

\begin{tabular}{ccc}
\hline & BIMODAL & PROACTIVE \\
\hline $\mathbf{1}$ & 62,97 & 30,74 \\
$\mathbf{2}$ & 58,27 & 29,90 \\
$\mathbf{3}$ & 67,15 & 24,40 \\
$\mathbf{4}$ & 61,84 & 27,92 \\
$\mathbf{5}$ & 60,78 & 23,17 \\
Média & $\mathbf{6 2 , 2}$ & $\mathbf{2 7 , 2 2}$ \\
\hline dp & $\mathbf{3 , 2 6}$ & $\mathbf{3 , 3 3}$ \\
\hline
\end{tabular}

\section{Análise topográfica}

Os implantes utilizados no presente estudo apresentam, de acordo com o fabricante, tratamento de superfície por jateamento com areia e ataque ácido. Microscopicamente, no MEV, a superfície Bimodal apresentou-se irregular e uniforme. No aumento de 5000x, observa-se rugosidade constituída por múltiplas lacunas heterogêneas, variando em média de $0,5 \mu \mathrm{m}$ à $1,5 \mu \mathrm{m}$ de diâmetro nas regiões cervical e apical do implante (Figura 21). A superfície ProActive apresentou superfície com menos irregularidades. No aumento de 5000x nota-se orifícios menos numerosos com maior diâmetro e menor profundidade quando comparado à superfície Bimodal. Morfologicamente, assume aspecto de escamas com presença de múltiplas partículas dispersas na sua superfície com média de 0,3 a 0,5 $\mu \mathrm{m}$ de diâmetro (Figura 22). 

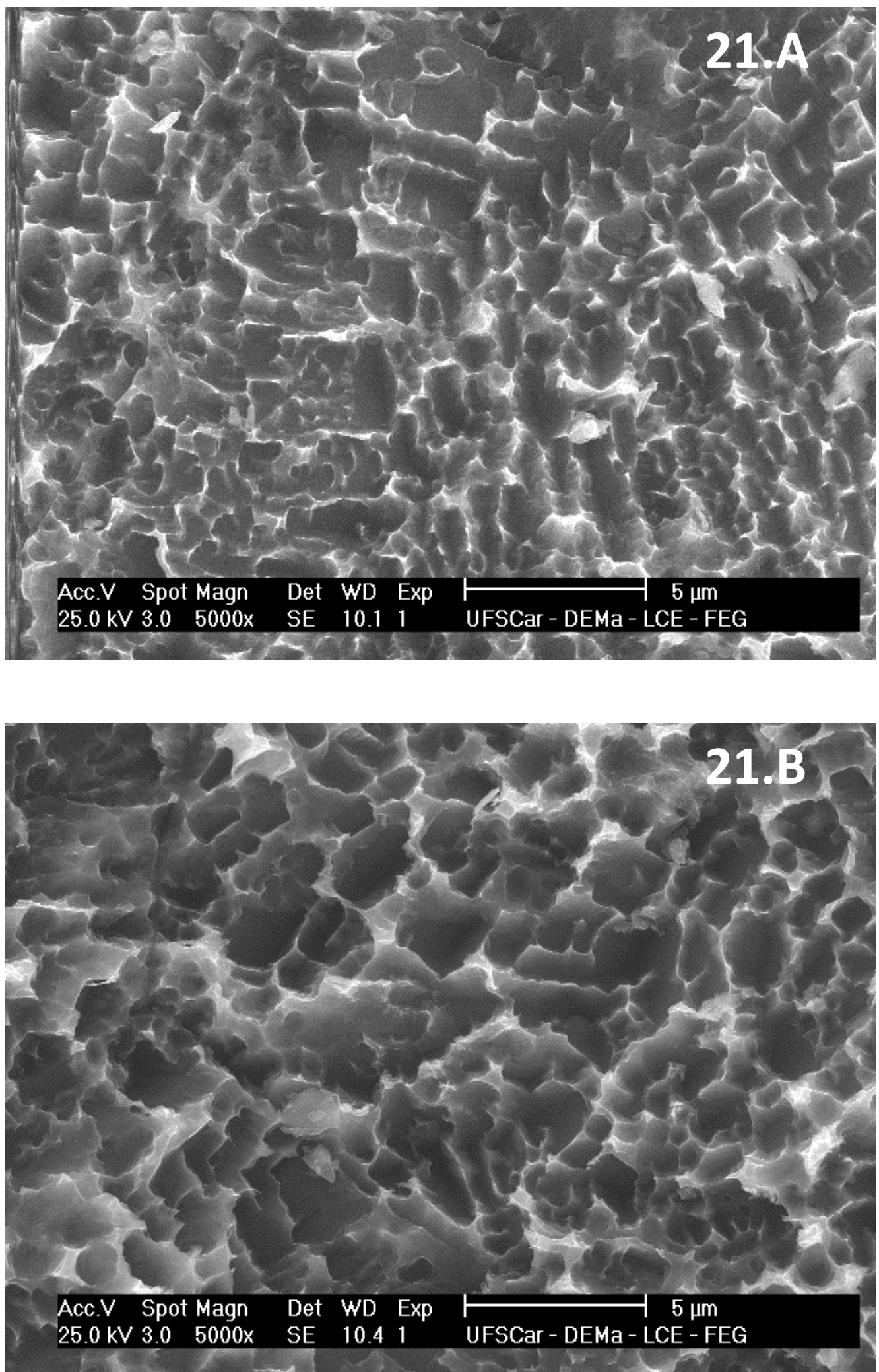

Figura 21 - Análise à MEV da região cervical (A) e apical (B) da superfície Bimodal $\AA$ (aumento de 5000x). 

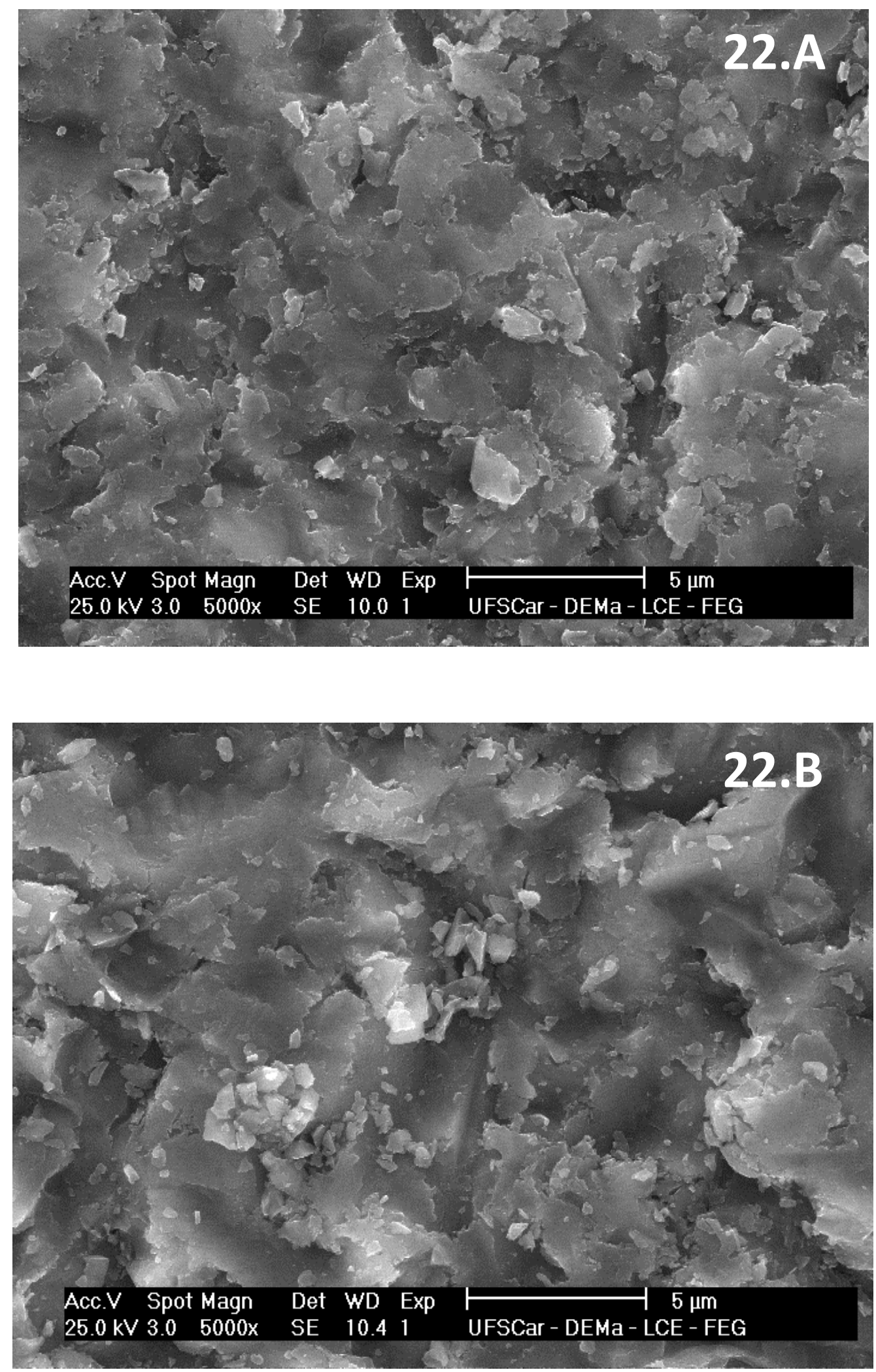

Figura 22 - Análise à MEV da região cervical (A) e apical (B) da superfície ProActive ${ }^{\circledR}$ (aumento de 5000x). 
Confirmando as observações da MEV, os valores da média de rugosidade $\left(S_{\mathrm{a}}\right)$ e porcentagem do aumento da superfície $\left(S_{\mathrm{dr}}\right)$, avaliados pela interferometria óptica, foram maiores para a superfície controle comparada com a superfície ProActive, os valores da densidade de pico $\left(S_{d s}\right)$ foram idênticos. Os dados estão descritos na Tabela 9.

Tabela 9 - Comparação entre as médias de Sa, Sdr e Sds avaliadas nas duas superfícies

\begin{tabular}{ccccccc}
\hline & \multicolumn{3}{c}{ BIMODAL } & \multicolumn{3}{c}{ PROACTIVE } \\
\hline & Sa $(\mu \mathrm{m})$ & $S d r(\%)$ & $\begin{array}{c}S d s \\
\left(1 / \mu m^{2}\right)\end{array}$ & $S a(\mu m)$ & $S d r(\%)$ & $\begin{array}{c}S d s \\
\left(1 / \mu m^{2}\right)\end{array}$ \\
Média & 0.8 & 16.9 & 0.1 & 0.4 & 8.0 & 0.1 \\
$\boldsymbol{d p}$ & 0.1 & 3.8 & 0.0 & 0.1 & 1.7 & 0.0 \\
\hline
\end{tabular}




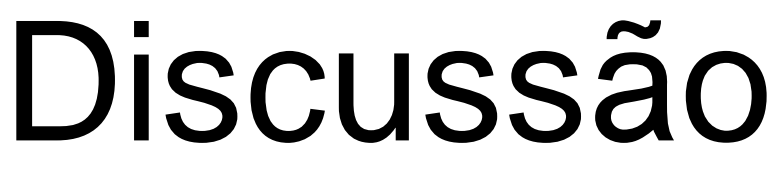




\section{DISCUSSÃO}

Modificações da superfície do implante têm o objetivo de aumentar a qualidade da ancoragem óssea ao redor do implante e diminuir o tempo da osseointegração em pacientes que necessitem de reabilitação em regiões onde a qualidade óssea se apresente como obstáculo para a osseointegração, como em osso do tipo III e IV de acordo com a classificação de Lekholm \& Zarb (1985), auxiliando, portanto o sucesso deste tipo de tratamento.

O presente estudo comparou duas superfícies de implantes supostamente diferentes em relação à hidrofibilidade de superfície durante a interação com o plasma sanguíneo. Foram utilizados parâmetros de histologia histomorfometria, fluorescência, análise de frequência de ressonância, teste de molhabilidade das superfícies e avaliação da rugosidade das superfícies visando verificar a resposta de células da linhagem osteoblástica na superfície do implante. Ao nosso conhecimento, este é o primeiro estudo experimental a utilizar uma variedade de parâmetros para avaliar a resposta de superfície hidrofílica de implantes. Importante lembrar que a diferença entre o metabolismo ósseo do cão e do humano possui tempos diferentes para o remodelamento ósseo. De acordo com Roberts et al. (1993), esta diferença é de 1/3 maior nos cães, desta forma, o período de acompanhamento de 7 e 30 dias realizados nos cães do presente estudo podem ser transpostos para humanos, equivalendo ao período de 9 e 40 dias, respectivamente.

A análise histológica revelou predominância de tecido de granulação e ausência de coágulo em 1 e 4 semanas. Em superfícies tratadas, a colonização da superfície do titânio por células de linhagem osteoblástica e consequente 
deposição da matriz óssea nessa superfície, promoveria a formação óssea na superfície do implante pela osteogênese de contato (DAVIES, 1998). Na quarta semana de reparo ósseo pôde-se notar a presença de osso imaturo originado das paredes ósseas e da base do defeito, tipicamente correspondendo à osteogênese à distância, como já relatada em estudos anteriores com superfícies hidrofílicas (BUSER, et al. 2004; LAl, et al 2009; FAVERO et al., 2012). Este vetor de formação também pode ser visualizado durante a análise da fluorescência, que marca a deposição da matriz óssea iniciando nas paredes ósseas do defeito. Na região apical do implante pôde ser notada atividade de deposição óssea lembrando processo de osteogênese de contato.

Houve um aumento significativo no valor do BIC entre a primeira e quarta semana de osseointegração, quando o comportamento das superfícies foi comparado, entretanto não houve diferença entre grupos em cada tempo avaliado. Em estudo utilizando minipigs comparando duas superfícies com topografias semelhantes e diferindo pela hidrofibilidade, Buser (2004) reportou aumento de contato ósseo de $20 \%$ na superfície hidrofílica após 2 semanas de instalação. Esta diferença diminuiu para 15\% após quatro semanas e foram iguais após 8 semanas de instalação do implante. Em estudo semelhante utilizando cães, Borstein (2008) encontrou aumento de $6 \%$ do BIC no grupo hidrofílico após 2 semanas de instalação e não encontrou diferença entre os grupos em 4 semanas. Utilizando os mesmos tempos de avaliação do trabalho anterior, Lang et al (2011) encontrou diferença de $16 \%$ após 4 semanas, não observando diferença entre os grupos após 2 e 8 semanas de osseointegração. Os resultados dos estudos anteriores mostram que o BIC foi maior em 2 semanas e 4 semanas em implantes com superfícies 
hidrofílicas. No nosso estudo não houve diferenças entre grupos em 1 e 4 semanas.

No presente estudo os valores de BA aumentaram significativamente quando comparados o período de 1 semana com 4 semanas de osseointegração, não houve diferença estatisticamente significante quando comparadas as superfícies testadas dentro de cada tempo avaliado. De maneira semelhante, a distância entre o ombro do implante e o primeiro contato ósseo (IS-C) não diferiram entre grupos.

Avaliando-se a neoformação óssea na região do defeito, encontramos aumento significativo na quantidade de neoformação óssea entre os tempos de 1 semana e 4 semanas, sem que exista diferença entre as superfícies avaliadas. Em um estudo semelhante, com confecção de GAPs de 0,5 e 0,75mm, a superfície hidrofílica favoreceu significantemente a neoformação óssea na região do defeito durante as 4 primeiras semanas de osseointegração. Após 8 semanas, os valores de formação óssea era semelhante entre as duas superfícies (LAI et al., 2009). Em análise histológica de implantes instalados com fenestração da parede vestibular, Schwarz et al. (2007) observou proliferação e maturação precoce do tecido ósseo sobre a superfície exposta do implante hidrofílico quando comparado à superfície convencional.

No presente estudo, ambas as superfícies apresentaram aumento do valor do ISQ entre a semana 1 e a semana 4 de avaliação, embora sem diferença entre os grupos. Este dado sugere que as propriedades hidrofílicas da superfície não alteraram o padrão de estabilidade dos implantes. Em estudo que comparou em 6 semanas valores de ISQ de implantes com superfícies hidrofílicas e convencionais, 
Oates et al. (2007) reportaram perda de estabilidade nas duas primeiras semanas de reparo com as duas superfícies testadas. A partir de 4 semanas a estabilidade dos implantes aumentou em ambas as superfícies e se comportaram de maneira similar até o final dos experimentos (6 semanas). O fato de não existir o tempo 1 no artigo de Oates et al (2007) invalida comparações de estabilidade em tempos mais precoces entre esses estudos. Um pequeno decréscimo da estabilidade durante as três primeiras semanas de reparo com posterior aumento dos índices foi relatado por autores que acompanharam o processo de osseointegração durante 12 semanas em humanos por meio da RFA. As superfícies convencional (SLA) e hidrofílica (SLAactive) apresentaram comportamento semelhante ao longo do período avaliado. Ambas superfícies apresentaram diminuição dos valores de ISQ durante as 3 primeiras semanas após a instalação dos implantes, após este período, ocorreu inversão da curva decrescente, com aumento da estabilidade até o final do período de acompanhamento (VALDERRAMA et al. 2007; HAN et al. 2010). Segundo Abrahamsson (2004), no momento da instalação a estabilidade do implante depende do embricamento do implante com o trabeculado ósseo. Nas semanas subsequentes, ocorre um processo de remodelação que envolve inicialmente reabsorção seguida por aposição óssea ao redor da superfície. No presente trabalho os valores de ISQ apresentaram aumento nos dois tempos avaliados de 1 e 4 semanas de reparo. Transpondo para humanos, os períodos analisados em cães no nosso estudo corresponderiam a 10 e 40 dias. Entretanto, não houve diferenças em ISQ entre as superfícies convencional e hidrofílica.

A microrugosidade da superfície dos implantes exerce importante influência na osseointegração dos implantes, sendo os melhores resultados apresentados 
pelas superfícies moderadamente rugosas (Sa entre 1 e $2 \mu \mathrm{m}$ ) (ALBREKTSSON e WENNEMBERG, 2004; WENNERBERG e ALBREKTSON 2009 E 2010). A superfície Bimodal é criada por bombardeamento de esferas de $\mathrm{ZrO}_{2}$ de 100 a 300 $\mu \mathrm{m}$ de diâmetro e em sequência bombardeados com partículas irregulares à base de TiO com tamanho de 75 a 150 $\mu$ m (BOGAERDE et al., 2008; SALATA et al., 2008). A superfície ProActive, sofre o mesmo processo de caracterização topográfica, porém é submetida a um processo subsequente de eliminação de carbono de sua superfície que confere a capacidade de melhor aproximação de fluidos. Durante a visualização topográfica utilizando microscopia eletrônica de varredura (MEV), é possível constatar diferenças entre as características físicas das superfícies, sendo observado na superfície ProActive irregularidades mais suaves com relação à superfície Bimodal e presença de partículas dispersas em toda sua extensão. Estas partículas não estavam presentes na superfície Bimodal.

Nos testes topográficos realizados, por meio de intereferometria óptica, os implantes Bimodal e ProActive neste estudo apresentaram rugosidades modestas. A superfície Bimodal apresentou Sa de 0,8 e Sdr de 16,9\% e valores menores na superfície ProActive com Sa de 0,4 e Sdr de 8\%, confirmando as observações das imagens obtidas pela análise com MEV. Em uma revisão sobre diversas superfícies, Wennerberg e Albrektsson (2009) relataram que os implantes mais utilizados atualmente, os valores de Sa e Sdr (\%) variaram de 0,3 e 24\% (superfície mais lisa) e 175 a 143\% (superfície mais rugosa). Apesar de não existir estudos comparativos experimentais, valores semelhantes aos implantes utilizados no presente estudo foram encontrados na superfície Nanotite (Biomet 3i) apresentando Sa de 0,5 e Sdr de 40\% com alta taxa de sucesso relatada após um 
ano da instalação com carga imediata (OSTMAN et al, 2012). Atualmente existem superfícies tratadas que, apesar da presença de rugosidades menores em relação aos implantes usinados, possuem valores de Sa de 0,9 e Sdr de $34 \%$ e demonstram resultados clínicos favoráveis (WENNEMBERG E ALBREKTSSON, 2009). Em estudos diferentes comparando as superfície TiUnite (Nobel Biocare Ab) e Bimodal, a primeira indicou valores mais exuberantes de Sa $(1,1)$ e Sdr $(37 \%)$ (SALATA et al., 2008) e no presente estudo a superfície Bimodal exibiu Sa de 0,8 e Sdr de $16,9 \%$. Assim, apesar da diferença entre topografias ambas as superfícies apresentaram BIC e BA semelhantes após 4 meses de osseointegração. Após a conclusão das análises, obtivemos por intermédio da empresa Neoss a sugestão que os implantes ProActive deveriam ser lavados para uma leitura fidedigna da superfície, indicando que as partículas observadas na MEV seriam responsáveis pela propriedade hidrofílica e seriam dissolvidas em contato com líquidos. Devido à indisponibilidade de implantes, a análise não pode ser repetida nas condições indicadas pela empresa.

A aferição do ângulo formado entre a água e a superfície de discos de titânio indica a capacidade de quebra da tensão superficial do líquido pela superfície. Como esperado, a superfície que resultou menor formação de tensão superficial nos líquidos foi a ProActivel, com formação de ângulo de $27,22^{\circ}$ em contato com o líquido, enquanto a superfície Bimodal apresentou valores de $62,2^{\circ}$. Apesar do aumento da umectibilidade observada na superfície ProActive, a tensão superficial presente impediu valores próximos à $0^{\circ}$ encontrados por Buser et al, $2004 \mathrm{e}$ Hyrakawa et al., 2012 quando testaram a superfície SLAactive. A superfície com maior capacidade de molhabilidade (ProActive) no nosso estudo não permitiria a 
aproximação dos fluidos tão eficientemente quanto desejada pelas superfícies altamente hidrofílicas. A característica hidrofílica do titânio é conferida pelo processo de remoção de carbono de sua superfície, hidroxilação da camada de óxido e armazenamento desse material em uma solução isotônica de $\mathrm{NaCl}$, que impede a contaminação do material (RUPP et al., 2006). Segundo esse autor, a ausência do acondicionamento em solução isotônica dos implantes utilizados poderia gerar uma perda da energia de superfície, com consequente perda da propriedade hidrofílica. Apesar dos implantes utilizados no presente estudo não serem acondicionados em solução isotônica, o tratamento conferido a eles não foi elucidado pelo fabricante, podendo ser diferente do processo aplicado à superfície SLAactive.

As modificações na superfície do titânio em implantes dentários visam à melhorar resultados clínicos, reduzindo o tempo de reparo e osseointegração. Isso não ocorreu com a superfície ProActive. Em nosso estudo, a osseointegração da superfície hidrofílica não foi diferente da superfície convencional, quando utilizado modelo experimental in vivo em tempos precoces de osseointegração. A literatura pertinente revela falta de homogeneidade de resultados quanto à superioridade da superfície hidrofílica sobre superfícies convencionais. Estudo in vitro relatou deposição de matriz óssea em período precoce em superfícies rugosas (SLA e SLAactive) quando comparada com superfície usinada, sendo que hidrofibilidade da superfície não influenciou a formação da matriz (WALL et al., 2009). Estudos clínicos e experimentais in vivo são escassos envolvendo superfícies hidrofílicas. A maior parte dos autores encontraram valores que apontam aumento da atividade osteoblástica em superfícies com umectibilidade aumentada, entretanto, não existe 
consenso quantitativo a respeito da influência da superfície sobre a osseointegração. Valores modestos como observado em nosso estudo foram relatados por Borstein et al. (2008), em estudo em cães. Esses autores encontraram aumento de $6 \%$ do BIC após 2 semanas de osseointegração na superfície hidrofílica em relação à superfície convencional, mas após 4 semanas não houve diferença estatística entre as duas superfícies. Em experimento semelhante, Hyrakawa et al. 2012 constataram aumento de 14\% do BIC na segunda semana de osseointegração de implantes hidrofílicos, sem diferença estatística à partir da quarta semana. Em contrapartida, Lai et al. (2009), reportaram valores de aumento de $23 \%$ do BIC nas superfícies hidrofílicas na segunda semana de osseointegração e $15 \%$ na quarta semana, achados semelhantes ao estudo de Buser et al. (2004) utilizando as mesmas superfícies em minipigs.

Aparentemente, os resultados dos estudos clínicos utilizando implantes hidrofílicos apontam a tendência do aumento da deposição óssea ao redor das superfícies ProActive na segunda semana de osseointegração, com diminuição desta diferença em relação aos implantes convencionais na quarta semana. $O$ presente trabalho avaliou os eventos biológicos ocorridos na primeira e quarta semana após a instalação dos implantes. A diferença entre os resultados obtidos dos estudos anteriores pode ser relacionada aos tempos experimentais utilizados, sendo uma semana, um período ainda precoce para se obter resposta dos eventos celulares induzidos e, quatro semanas, comportamento semelhante entre as duas superfícies como relatado nos demais estudos clínicos. Além disso, a hidrofibilidade moderada apresentada pelos implantes utilizados poderia limitar as 
respostas biológicas observadas pelos autores que utilizaram superfícies altamente hidrofílicas.

O papel exato da energia de superfície dos implantes dentais sobre os eventos de osseointegração bem como sua manutenção à longo prazo ainda permanece com alguns pontos obscuros. As técnicas para a obtenção deste tipo de propriedade não são completamente esclarecidas. Os implantes utilizados nos estudos envolvendo hidrofibilidade são acondicionados imersos em líquido para manutenção da propriedade adquirida com o tratamento de superfície. Os implantes testados no presente estudo são acondicionados em embalagens sem presença de líquidos. Os valores apresentados pela superfície ProActive no teste de hidrofibilidade se mostraram superiores em relação à superfície Bimodal, porém inferiores ao compararmos a superfície dos implantes SLAactive, próxima à zero segundo os relatos de Buser, 2004. Devido a diferença de acondicionamento dos implantes e valores obtidos no teste de molhabilidade, podemos suspeitar que existe diferença no processo que confere ao implante a propriedade hidrofílica.

Devido a grande controvérsia de resultados, abre-se uma lacuna para se acreditar que a osseointegração dos implantes pode ser favorecida por fatores como a qualidade óssea, técnica cirúrgica, estabilidade inicial do implante, resposta individual do paciente à inflamação. Sendo que a influência da hidrofibilidade, responde de maneira menos acentuada que fatores individuais atribuídos ao paciente como hábitos deletérios ou condições sistêmicas que respondem pela capacidade individual de reparo ósseo. 
Conclusões 


\section{CONCLUSÕES}

Com base nos resultados obtidos pode-se concluir:

1- A superfície ProActive apresentou valores menores de rugosidade e aumento da umectibilidade em relação aos implantes com superfície Bimodal;

2- A superfície ProActive utilizada no presente estudo não favoreceu os eventos de osseointegração nas condições períodos de 1 e 4 semanas avaliados;

3- Após 4 semanas de osseointegração, ocorreu aumento da estabilidade dos implantes instalados sem haver diferença entre as superfícies ProActive e Bimodal; 


\section{REFERÊNCIAS $\$$}

1. Abrahamsson I, Berglundh T, Linder E, Lang NP, Lindhe J. Early bone formation adjacent to rough and turned endosseous implant surfaces. An experimental study in the dog. Clin Oral Implants Res. 2004 Aug;15(4):38192.

2. Albrektsson T, Brånemark P.-I, Hansson H.A. Lindström J. Osseointegrated titaniumimplants. Requirements for ensuring a long-lasting, direct bone-toimplant Anchorage in man. Acta Orthopaedica Scandinavica 1981;52:15570.

3. Albrektsson T, Wennerberg A. Oral implant surfaces: Part 1 - Review focusing on topographic and chemical properties of different surfaces and in vivo responses to them. In J Prosthodont 2004;17:536-46.

4. Albrektsson T, Wennerberg A. Oral implant surfaces: Part 2 - Review focusing on clinical knowledge of different surfaces. Int J Prosthodont 2004;17:544-64.

5. Anselme K, Bigerelle M, Noel B, Dufresne E, Judas D, lost A, et al. Qualitative and quantitative study of human osteoblast adhesion on materials with various surface roughnesses. J Biomed Mater Res. 2000;49(2):155-66.

6. Aparicio C, Gil FJ, Fonseca C, Barbosa M, Planell JA. Corrosio behaviour of commercially pure titanium shot blasted with different materials and sizes of shot particles for dental implant applications. Biomaterials. 2003 Jan;24(2):263-73.

7. Bereznai M, Pelsöczi I, Tóth Z, Turzó K, Radnai M, Bor Z, Fazekas A. Surface modifications induced by ns and sub-ps excimer laser pulses on titanium implant material. Biomaterials. 2003 Oct;24(23):4197-203.

8. Biesbrock AR, Edgerton M. Evaluation of the clinical predictability of hydroxyapatite-coated endosseous dental implants: a review of the literature. Int J Oral Maxillofac Implants. 1995 Nov-Dec;10(6):712-20.

${ }_{\S}^{\S}$ Baseadas na norma do International Committee of Medical Journal Editors (Vancouver), de 2009. 
9. Bogaerde LV, Pedretti G, Sennerby L, Meredith N. Immediate/Early function of Neoss implants placed in maxillas and posterior mandibles: an 18-month prospective case series study. Clin Implant Dent Relat Res. 2010 May;12 Suppl 1:83-94.

10. Bornstein M. M.; Valderrama P.; Jones A. A.; Wilson T. G.; Seibl R.; Cochran D. L. Bone apposition around two different sandbalsted and acid-etched tiatnium implant surfaces: a histometric study in canine mandibles.. Clin. Oral Impl. Res. v. 19, p. 233-241, 2008.

11. Brånemark $\mathrm{PI}$, Adell R, Breine U, Hansson BO, Lindström J, Ohlsson A. Intra-osseous anchorage of dental prostheses. I. Experimental studies. Scand J Plast Reconstr Surg. 1969;3(2):81-100.

12. Brånemark P. I., Hansson B. O, Adell R., Breine U, Lindstrom J., Hallen O., and. Ohman A. Osseointegrated implants in the treatment of the edentulous jaw. Experience from a 10-year period. Scand J. Plast Reconstr. Surg. Suppl. 16, 1 (1977).

13. Buser, D.; Dula, K.; Hess, D.; Hirt, H. P.; Berser, U. C. Localized ridge augmentation with autografts and barrier membranes. Periodontol. 2000., v. 19, p. 151-163, 1999.

14. Buser, D.; Schenk, R.K.; Steinemann, S.; Fiorellini, J.P.; Fox, C.H.; Stich, H. Influence of surface characteristics on bone integration of titanium implants. A histomorphometric study in miniature pigs. J. Biomed. Mater. Res., v.25, n.7, p.889-902, 1991.

15. Buser D, Broggini N, Wieland M, Schenk Rk, Denzer Aj, Cochran DI, Et Al. Enhanced bone apposition to a chemically modified SLA titanium surface. J Dent Res. 2004 Jul;83(7):529-33.

16. Carlsson L, Albrektsson T, Berman C. Bone response to plasma-cleaned titanium implants. Int J Oral Maxillofac Implants 1989;4:199-204.

17. Chehroudi B, Gould TR, Brunette DM. Effects of a grooved epoxy substratum on epithelial cell behavior in vitro and in vivo. J Biomed Mater Res. 1988 Jun;22(6):459-73. 
18. Davies, J. E. Mechanism of endosseous integration. Int J Prosthodont. 1998, 11: 391-401.

19. Dee KC, Rueger DC, Andersen TT, Bizios R. Conditions which promote mineralization at the bone-implant interface: a model in vitro study. Biomaterials. 1996 Jan;17(2):209-15.

20. Digidi M; Piattelli A; Shibli Ja; Perrotti V; lezzi G. Bone formation around onestage implants with a modified sandblasted and acid-etched surface. human histologic results at 4 weeks. Int. J. Periodontics Restorative Dent v. 29, n. 6, p. 607-613, 2009.

21. Donos, N., Hamlet, S., Salvi, G.E., Huynh-Ba, G.Bosshardt, D.D., Lang, N.P. \& Ivanovski, S. Comparison of gene expression profiling between hydrophilic and hydrophobic implant surfaces in humans.Clinical Oral Implants Research 22: 416-423, 2011.

22. Elias CN, Oshida Y, Lima JH, Muller CA. Relationship between surfasse properties (roughness, wettability and morphology) of titanium and dental implant removal torque. J Mech Behav Biomed Mater; 2008; 1(3):234-42.

23. Ehrenfest, D. M. D.; Coelho, P. G.; Kang, B.; Sul, Y-T.; Albrektsson, T. Classification of osseointegrated implant surfaces: materials, chemistry and topography. Trends in Biotechnology, v. 28, n. 4, p. 198-206, 2010.

24. Favero G, Lang NP, Favero G, Leo'n IG, Salata LA, Botticelli D. Role of teeth adjacent to implants installed immediately into extraction sockets: an experimental study in the dog. Clin. Oral Impl Res. 00, 2011, 1-7.

25. Ganeles J, Zöllner A, Jackowski J, ten Bruggenkate C, Beagle J, Guerra F. Immediate and early loading of Straumann implants with a chemically modified surface (SLActive) in the posterior mandible and maxilla: 1-year results from a prospective multicenter study. Clin Oral Implants Res. 2008 Nov;19(11):1119-28.

26. Guéhennec, L. L.; et al. Surface treatments of titanium dental implants for rapid osseointegration. Dental Materials, v.23, n.7, p.844-854, 2006.

27. Hirakawa Y, Jimbo R, Shibata Y, Watanabe I, Wennerberg A, Sawase T. Accelerated bone formation on photo-induced hydrophilic titanium implants: 
an experimental study in the dog mandible. Clin Oral Implants Res. 2012 Jan 17.

28. Ivanoff CJ, Hallgren C, Widmark G, Sennerby L, Wennerberg A Histologic evaluation of the bone integration of $\mathrm{TiO}(2)$ blasted and turne titanium microimplants in humans. Clin Oral Implants Res. 2001 Apr;12(2):128-34.

29. Lai H-C, Zhuang L-E, Zhang Z-Y, Wieland M, Liu X.Bone apposition around two different sandblasted, large-grit and acid-etched implant surfaces at sites with coronal circumferential defects: an experimental study in dogs. Clin. Oral Impl. Res. 20, 2009; 247-253.

30. Lang NP, Salvi GE, Huynh-Ba G, Ivanovski S, Donos N, Bosshardt DD. Early osseointegration to hydrophilic and hydrophobic implant surfaces in humans.Clin. Oral Impl. Res. 22; 349-356, 2011.

31. Lavos-Valereto IC, Costa I, Wolynec S The electrochemical behavior of Ti$6 \mathrm{Al}-7 \mathrm{Nb}$ alloy with and without plasma-sprayed hydroxyapatite coating in Hank's solution. J Biomed Mater Res. 2002;63(5):664-70.

32. Lee J, Rouhfar L, Beirne O. Survival of hydroxypatite-coated implants: a meta-analytic review. J Oral Maxillofac Surg 2000;58:1372-9.

33. Li, D.H.; Liu, B.L.; Han, Y.; Xu, K.W. Effects of a modified sandblastig surface treatment on topographic and chemical properties of titanium surface. Implant Dent., v.10, n.1, p.59-64, 2001.

34. Liu, X.; Chu, P.K.; Ding, C. Surface modification of titanium, titanium alloys, and related materials for biomedical applications. Materials Science and Engineering: R: Reports, v.27, n.3-4, p.49-121, 2004.

35. Meirelles L, Currie F, Jacobsson M, Albrektsson T, Wennerberg A. The effect of chemical and nanotopographical modifications on the earlystages of osseointegration. Int J Oral Maxillofac Implants. 2008 Jul-Aug;23(4):641-7.

36. Olivares-Navarrete, R.; Hyzy, S. L.; Hutton, D. L.; Erdman, C. P.; Wieland, M.; Boyan, B. D.; Schwartz, Z. Direct and indirect effects of microstructured titanium substrates on the induction of mesenchymal stem cell differentiation towards the osteoblast lineage. Biomaterials. v. 31, n.10, p. 2728-35, 2010. 
37. Ong JL, Carnes DL, Bessho K. Evaluation of titanium plasmasprayed and plasma-sprayed hydroxyapatite implants in vivo. Biomaterials. 2004 Aug;25(19):4601-6.

38. Ostman PO, Wennerberg A, Ekestubbe A, Albrektsson T. Immediate Occlusal Loading of NanoTite ${ }^{\mathrm{TM}}$ Tapered Implants: A Prospective 1-Year Clinical and Radiographic Study. Clin Implant Dent Relat Res. 2012 Jan 17.

39. Predecki P, Auslaender BA, Stephan JE, Mooney VL, Stanitski C. Attachment of bone to threaded implants by ingrowth and mechanical interlocking. J Biomed Mater Res. 1972 Sep;6(5):401-12.

40. Rupp F, Scheideler L, Olshanska N, de Wild M, Wieland M, Geis-Gerstorfer $\mathrm{J}$. Enhancing surface free energy and hydrophilicity through chemical modification of microstructured titanium implant surfaces. J Biomed Mater Res A. 2006 Feb;76(2):323-34.

41. Salata, L.A.; Faria, P.E.P.; Tavares, M.G.; Meredith, N.; Sennerby, L. Histological Evaluation of a Bimodal Titanium Implant surface. A Pilot Study in the Dog Mandible. Applied Osseointegration Research - v.6, 2008.

42. Schlegel KA, Prechtl C, Mo" st T, Seidl C, Lutz R, Von Wilmowsky C. Osseointegration of SLActive implants in diabetic pigs. Clin. Oral Impl. Res. 00, 2011, 1-7.

43. Schwartz, Z.; Boyan, B. D. J. Underlying mechanisms at the bonebiomaterial interface. Cell. Biochem. 1994, 56, 340.

44. Schwarz, F., Herten, M., Sager, M., Wieland, M., Dard, M. \& Becker, J. Histological and immunohistochemical analysis of initial and early osseous integration at chemically modified and conventional SLA titanium implants: preliminary results of a pilot study in dogs. Clinical Oral Implants Research 18: 481-488, 2007.

45. Schwarz, F., Herten, M., Sager, M., Wieland, M., Dard, M. \& Becker, J. Bone regeneration in dehiscence-type defects at chemically modified (SLActive) and conventional SLA titanium implants: a pilot study in dogs. Journal of Clinical Periodontology 34: 78-86, 2007. 
46. Sennerby, L.; Roos, J. Surgical determinants of clinical success of osseointegrated oral implants: A review of the literature. Int. J. Prosthodont., n. 11, p. $408-420,1998$.

47. Spiekermann, H. Implantologia. Porto Alegre, Artes médicas Sul, 2000, p.1158.

48. Stenz, W. C. Mealey, B. L. Nummikoski, P. V., Gunsolley, J. C., Wadrop, Tc. C. Effects of guided bone regeneration around commercially pure titatium and hidroxyapatite-coated dental implants I. Radiografic Analysis. J. Periodontol. V. 68, p. 199-208, 1997.

49. Valderrama P, Oates TW, Jones AA, Simpson J, Schoolfield JD, Cochran DL. Evaluation of two different resonance frequency devices to detect implant stability: a clinical trial. J Periodontol. 2007 Feb;78(2):262-72.

50. Wall, I., Donos, N.; Carlqvist., K.; Jones, F.; Brett, P. Modified titanium surfaces promote accelerated osteogenic differentiation of mesenchymal stromal cells in vitro. Bone 45 (2009) 17-26.

51. Wennerberg A, Albrektsson T, Andersson B, Krol JJ. histomorphometric and removal torque study of screw-shaped titaniu implants with three different surface topographies. Clin Oral Implants Res 1995 Mar;6(1):24-30.

52. Wennemberg, A.; Albrektsson, T. On implant surfaces: A review of current knowledge and opinions. Int. J. Oral Maxillof. Implants. v.24 p. 63-74, 2009.

53. Wennerberg A, Albrektsson T. Effects of titanium surface topography on bone integration: a systematic review. Clin. Oral Impl. Res. 20 (Suppl. 4), 2009; 172-184.

54. Wennerberg A, Albrektsson T. On implant surfaces: a review of current knowledge and opinions. Int J Oral Maxillofac Implants. 2010 Jan-Feb; 25(1): 63-74.

55. Zhao G, Schwartz Z, Wieland M, Rupp F, Geis-Gerstorfer J, Cochran D, et al. High surface energy enhances cell response to titanium substrate microstructure. J Biomed Mat Res. 2005;74A(1):49-58. 
Página| 73

Anexos 


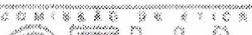

$(y)(1) / 4$

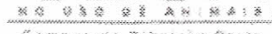

UNIVERSIDADE DE SÃO PAULO

Campus de Ribeirão Preto

Coxprsabu de Etica no Uso de Amimais

\section{E R T I I C A D O}

Certificamos que o trabalho (Protocolo $n^{\circ}$ 10.1.973.53.1), intitulado "Efeito da Hidrofilia da Superficie de Titânio na Estabilidade do Implante em Defeitos Ósseos Marginais em Mandibula de Cäes", de autoria de Gustavo Augusto Grossi de Oliveira, e de Luiz Antonio Salata por estar de acordo com os Principios Éticos na Experimentação Animal adotado pela Comissão de Ética no Uso de Animais (CEUA) do Campus de Ribeirāo Preto - USP fol aprovado em reunião da CEUA do $0411 / 2010$

This is to certify that the work (Protocol number 10.1.973.53.1), entivled: "Efeito da Hidrofilia da Superficie de Titânio na Estabilidade do Implante em Defeltos Ósseos Marginais em Mandibula de Cáes", by Gustavo Augusto Grossi de Oliveira and Luiz Antonio Salata, is in accordance with the Ethic Principles in Animal Experimentation adopted by Ethic Commission for the Use of Animals (CEUA) of the Campus of Ribeirăo Preto - USP, and was approved in the meeting, November 04 2010.

Chutal lab boum

Presidente da CEUA

Profa Dra. Christie Ramos Andrade Leite Panissi

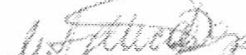

Secretaria da CEUA

Mária Angélica Depiro

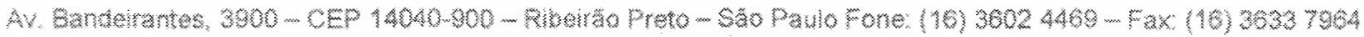

